medRxiv preprint doi: https://doi.org/10.1101/2021.09.17.21263549; this version posted September 25, 2021. The copyright holder for this

preprint (which was not certified by peer review) is the author/funder, who has granted medRxiv a license to display the preprint in perpetuity.

It is made available under a CC-BY 4.0 International license .

\title{
A systematic review of COVID-19 vaccine efficacy and effectiveness against SARS-CoV-2 infection and disease
}

Melissa M Higdon ${ }^{1,2}$, MPH; Brian Wahl', 2, PhD; Carli B Jones ${ }^{3}$, BS; Joseph G Rosen ${ }^{1}$, MSPH; Shaun A Truelove ${ }^{1,2}, \mathrm{PhD}$; Anurima Baidya ${ }^{2}, \mathrm{MBBS}$; Anjalika A Nande ${ }^{4}, \mathrm{PhD}$; Parisa A ShamaeiZadeh ${ }^{2}$, BS; Karoline K Walter ${ }^{2}$, BA; Daniel R Feikin ${ }^{5}$, MD; Minal K Patel ${ }^{5}$, MD; Maria Deloria Knoll ${ }^{1,2}$, PhD; Alison L $\mathrm{Hill}^{4}, \mathrm{PhD}$

${ }^{1}$ Department of International Health, Johns Hopkins Bloomberg School of Public Health, $415 \mathrm{~N}$ Washington St, Baltimore, MD, USA, 21231

${ }^{2}$ International Vaccine Access Center, Johns Hopkins Bloomberg School of Public Health, $415 \mathrm{~N}$ Washington St, Baltimore, MD, USA, 21231

${ }^{3}$ Department of Pathology Johns Hopkins University School of Medicine, $600 \mathrm{~N}$ Wolfe St, Baltimore, MD, USA, 21287

${ }^{4}$ Institute for Computational Medicine, Johns Hopkins University, 3400 N Charles Street, Baltimore, MD, USA, 21218

${ }^{5}$ Department of Immunization, Vaccines, and Biologicals, World Health Organization, Avenue Appia 20, Geneva, Switzerland, 1211

Correspondence: Alison L Hill, Institute for Computational Medicine, Johns Hopkins University, $3400 \mathrm{~N}$ Charles Street, Baltimore, MD, USA, 21218, alhill@jhmi.edu

Keywords: COVID-19, SARS-CoV-2, vaccine efficacy, vaccine effectiveness, systematic review

\section{ABSTRACT}

Billions of doses of COVID-19 vaccines have been administered around the world, dramatically reducing SARS-CoV-2 incidence in some settings. Many studies suggest vaccines provide a high degree of protection against infection and disease, but precise estimates vary and studies differ in design, outcomes measured, dosing regime, location, and circulating virus strains. Here we conduct a systematic review of COVID-19 vaccines as of August 2021. We included efficacy data from Phase 3 clinical trials for 13 vaccines within the WHO Emergency Use Listing evaluation process and real-world effectiveness for 5 vaccines with observational studies meeting inclusion criteria. Vaccine metrics collected include effects against asymptomatic infection, any infection, symptomatic COVID-19, and severe outcomes including hospitalization and death, for both partial and complete vaccination, and against SARS-CoV-2 variants of concern. In addition, we review the epidemiological principles behind the design and interpretation of vaccine effects and explain important sources of heterogeneity between studies. 


\section{MAIN TEXT}

\section{Introduction}

On March 11, 2020, the World Health Organization (WHO) declared SARS-CoV-2 a global pandemic ${ }^{1}$ Worldwide, over 200 million COVID-19 cases and over 4 million deaths have been recorded to date. SARS-CoV-2's rapid global spread and its alarming clinical severity have accelerated demand for COVID-19 immunizations that safely and effectively prevent disease incidence or reduce severity. Despite the traditionally prolonged vaccine development timeline, over 20 COVID-19 vaccine candidates have received emergency use authorization in at least one country, and 3 billion people have been vaccinated globally ${ }^{2,3}$.

Evidence from clinical trials and observational studies overwhelmingly support the safety and immunogenicity of numerous COVID-19 vaccines, especially when it comes to protection against severe infection and death in fully vaccinated individuals. However, precise estimates of vaccine efficacy and effectiveness ("VE") have varied across studies due to a range of factors. For example, an interim analysis across four Phase 3 trial sites found AstraZeneca's two-dose viral vector vaccine (AZD1222) had 70\% efficacy against symptomatic COVID-19 disease; when disaggregated by dosing schedule, estimated VE was nearly $30 \%$ higher in the sub-cohort receiving a modified low vaccine dose followed by a standard dose (90\%) compared to the sub-cohort receiving two standard doses $(62 \%)^{4}$. Observational studies in the $\mathrm{UK}^{5-8}$, Scotland ${ }^{9}, \mathrm{Brazil}^{10}$, and the Netherlands ${ }^{11}$, have since presented a range of VE estimates (60\% to $94 \%$ ) obtained from non-randomized designs (i.e., test-negative control, prospective cohort) using effectiveness measures (e.g., any SARS-CoV-2 infection) differing from the outcomes of the clinical trials.

SARS-CoV-2 evolutionary dynamics have further confounded interpretation of heterogeneous VE estimates obtained from comparably designed COVID-19 vaccine studies, particularly under real-world, non-experimental conditions. The emergence of SARS-CoV-2 strains designated variants of concern (VOC) by WHO, including Alpha (B.1.1.7), Beta (B.1.351), Gamma (P.1), and Delta (B.1.617.2), has recently increased concern over attenuated VE given that some variants are associated with higher viral load $^{12-16}$ and evasion of neutralizing antibodies ex vivo ${ }^{17-19}$. Recent studies have reported diminished effectiveness of the Pfizer-BioNTech BNT162b2 vaccine against the Delta SARS-CoV-2 variant $^{20,21}$, relative to the $95 \%$ VE measure against parent SARS-CoV-2 lineages obtained from clinical trials $^{22}$. Efforts to attribute these observed reductions to waning immunity, diminished protection against circulating SARS-CoV-2 variants, study methodology, or other contextual factors (i.e., presence vs absence of non-pharmaceutical interventions) is constrained by their co-occurrence and endogeneity. Nonetheless, synthesizing the totality of the evidence for COVID-19 VE, and understanding the constellation of factors contributing to observed heterogeneities, is imperative for policy-makers to design effective and equitable COVID-19 vaccination campaigns during a rapidly evolving pandemic.

Here, we systematically reviewed vaccine efficacy and effectiveness data for COVID-19 vaccines against various clinical outcomes, specifically asymptomatic infection, any infection, symptomatic disease, hospitalization, and death. Additionally, our review considers VE measures for both full and partial immunization courses and circulating SARS-CoV-2 variants of concern. 


\section{Methods}

For the purpose of this study, we use the abbreviation "VE" to refer to both vaccine efficacy (from randomized clinical trials) and vaccine effectiveness (from observational studies). We chose to review all vaccines which had received, or submitted applications for, Emergency Use Listing from WHO as of August 15, $2021^{23}$ and had at minimum publicly released data from completed Phase 3 trials (Table 1). We searched for clinical trial efficacy results published in peer-reviewed scientific journals (PubMed, Google Scholar), preprint servers (medRxiv, bioRxiv), government public health agency websites, in news articles (Google), on the vaccine manufacturers' websites, and in the databases of medical regulatory agencies (e.g., the US Food \& Drug Administration or the European Medicines Agency). Searches were conducted using the vaccine's brand, trade, or research name. To locate observational studies of vaccine effectiveness, we used a detailed search query applied to multiple databases (Supplementary Methods), and only included results that appeared in at least a detailed report or preprint form. Studies underwent an initial review of the title/abstract, before progressing to a more detailed full-text review (Figure S1). From each document, we extracted VE against any stage of infection (Table S1). For the full vaccine course (1 or 2 doses, depending on the vaccine brand), results were only included if at least 1 week had passed between the final dose and case detection. For VE after a partial course, cases must have occurred at least 2 weeks after the first dose but before the second dose.

Observational studies were excluded if a proper control group was not used (e.g., modeled or historic controls), outcomes were not laboratory-confirmed, the study design did not attempt to account for confounding, vaccination status was determined by self-report (not documented) for $>10 \%$ of participants, confidence intervals (Cls) were not reported (except in cases where it was not possible to calculate Cls), significant bias was present as determined by expert opinion, if the early post-vaccination period was used as the reference period for calculating VE (e.g., day 0-12 vs. day 12-21), or if the definition of unvaccinated included days 0-12 post vaccination. For this review only studies including persons with and without the clinical outcome under investigation and with and without vaccination were included. Thus, impact studies and studies that only evaluated the risk of progression to severe disease among SARS-CoV-2-positive individuals were excluded. We evaluated studies that reported VE for a combination of vaccines but did not include those values here unless they also disaggregated results by vaccine product. Finally, we excluded studies that only presented 1st dose VE of a 2-dose vaccine while including some persons who had received 2 doses in the estimate. We classified VE as specific against a particular SARS-CoV-2 variant if sequencing or other molecular detection methods were used within the study to confirm the variant causing infection in all individual cases contributing to a VE estimate. The data from observational studies included here is also available in table and graphical formats on VIEW-hub, a resource developed by the International Vaccine Access Center at Johns Hopkins University (view-hub.org/resources) and in the Data Supplement (Table S1).

\section{Defining how well a vaccine prevents infection and disease}

Like other pharmaceutical products, vaccines are evaluated in clinical trials for both safety and efficacy, and in this review, we focus on the latter. Vaccine efficacy is defined as the amount by which vaccination reduces the probability that an individual develops disease in a particular time period compared to those who did not receive the vaccine. It is calculated using this formula: 


$$
V E=1-\frac{\text { (\# cases among vaccinated } / \# \text { vaccinated })}{(\# \text { cases among unvaccinated } / \# \text { unvaccinated })}=1-\frac{\text { risk in vaccinated group }}{\text { risk in unvaccinated group }},
$$

where sometimes the denominator "\# vaccinated" ("\# unvaccinated") is replaced with the sum of the total time enrolled in the study among vaccinated (unvaccinated) subjects (i.e., the "person time") ${ }^{24,25}$.

Vaccine efficacy only describes the relative, as opposed to absolute, risk of disease. For example, if the risk of disease within a certain time frame is reduced from $50 \%$ in unvaccinated individuals to $10 \%$ in vaccinated individuals, then the vaccine efficacy $(80 \%)$ is the same as in another setting where the risk of disease in that time frame was reduced from $5 \%$ among the unvaccinated to $1 \%$ among the vaccinated. This is a desired feature of a metric for vaccine strength, since absolute risk may change over time during an epidemic, due to factors like seasonality and non-pharmaceutical interventions (e.g., shelter-in-place ordinances, face mask use). The value of vaccine efficacy also does not typically tell us how an imperfect vaccine fails. A $90 \%$ efficacious vaccine could mean one of three things: (1) that $90 \%$ of vaccinated individuals are completely resistant to disease while the other $10 \%$ are as susceptible as unvaccinated individuals ("all-or-nothing"), (2) that all vaccinated individuals have exactly $1 / 10$ th the risk of getting infected from any given exposure (i.e., a "leaky" vaccine), or (3) a combination of these scenarios ${ }^{25-27}$.

To measure vaccine efficacy for COVID-19 and in general, the specific clinical outcome that the vaccine is meant to prevent (the definition of "disease") must be carefully defined. The ideal goal of vaccination is to completely prevent infection, meaning that the vaccine-induced immune response must be able to block the earliest attempts of the pathogen to replicate within an individual's body. If infection cannot be established, then this individual will not experience symptoms of the disease nor transmit to susceptible individuals. This sort of "sterilizing immunity" is rare, and vaccine efficacy against infection is difficult to measure in practice ${ }^{28,29}$ since, for short-lived and commonly asymptomatic infections like SARS-CoV-2, this would require frequent testing of everyone in the study population. Moreover, high efficacy against infection is not necessary for a vaccine to be beneficial. To reduce the public health impact of an infectious disease, it might be enough to prevent the symptoms of the disease, even if infection still occurs $^{30}$. Even vaccines that do not completely prevent infection may trigger immune responses that can reduce viral load, the duration of infectiousness, or spread of virus between tissues, preventing deleterious clinical outcomes ${ }^{29-31}$.

For COVID-19, the primary vaccine efficacy outcome chosen as the endpoint for most clinical trials was the ability to prevent symptomatic, laboratory-confirmed COVID-19 disease ${ }^{30}$. This outcome was defined as the occurrence of COVID-19-associated symptoms (e.g., cough, shortness of breath, fever) occurring in the presence of detectable SARS-CoV-2. This definition of vaccine efficacy represents a trade-off between practicality and public health importance. Symptoms can be self-assessed by participants and testing restricted to those reporting symptoms. However, most individuals with COVID-19 recover completely with only mild or moderate symptoms, and the major concern is the subset of individuals who develop more severe disease ${ }^{32-34}$. While the fraction of infections progressing to a severe stage is high enough to have overwhelmed healthcare resources globally and led to millions of excess deaths in 2020 and 2021, it is still rare enough that few events would be expected to occur in a clinical trial of tens of thousands of individuals lasting a few months. While many trials did report efficacy against severe outcomes like hospitalization or death as secondary outcomes despite small numbers ${ }^{22,35-44}$, non-randomized post-approval studies provide further estimates of these metrics for 
medRxiv preprint doi: https://doi.org/10.1101/2021.09.17.21263549; this version posted September 25, 2021. The copyright holder for this preprint (which was not certified by peer review) is the author/funder, who has granted medRxiv a license to display the preprint in perpetuity.

It is made available under a CC-BY 4.0 International license.

much larger sample sizes. In this paper, we summarize vaccine efficacy and effectiveness values reported for all stages of infection from both clinical trials and observational studies.

\section{Randomized and observational studies for estimating vaccine effects}

Formally, the calculation of VE compares the likelihood of infection in vaccinated individuals to the hypothetical risk they would have had if they were unvaccinated. In reality, hypothetical comparisons are impossible and must be made between different groups of individuals. Vaccine studies therefore strive to choose comparable groups in terms of disease risk, so any observed differences between them can be attributed to vaccination. One approach is to conduct a study where subjects are randomly assigned to receive the vaccine or not, which, with large enough sample sizes usually ensures there will not be any significant differences. In reality, randomization is not always possible, so "observational" studies use data from situations where vaccine administration was non-random and attempt to isolate the effect of vaccination by accounting for differences between groups in the study design and analysis.

This review includes data from both randomized controlled trials (RCTs) that estimate vaccine efficacy and observational studies that report real-world vaccine effectiveness, which each have pros and cons $^{45,46}$. The most obvious strength of RCTs is that randomization helps ensure that the results are not biased by participants' health-seeking behaviors and risk factors for disease. While RCTs are the gold-standard for vaccine studies ${ }^{30}$, they are very costly and rarely include more than tens of thousands of participants. Consequently, the incidence of more severe outcomes of infection is often limited and long study durations may be needed. RCTs may exclude participants with a high risk of death, or populations who need the vaccine but who are too risky to include in the trial, such as pregnant women, young children, and those with comorbid health conditions. The age and race composition of trial populations may also be relatively homogenous. Finally, participants in an RCT may become unblinded if they are told their vaccination status by study administrators or infer it based on vaccine side effects, which can introduce bias or confounding into the study.

Once a vaccine is shown to be safe and efficacious in clinical trials and is authorized for general use, further randomized trials are often considered unethical or impractical, especially in the setting of a wide-spread epidemic like the COVID-19 pandemic. Instead, observational studies are used to augment estimates of vaccine efficacy with values of real-world effectiveness and include designs such as case-control studies (including test-negative designs) and cohort studies (prospective or retrospective $)^{25,47,48}$. Compared to RCTs, observational studies have their own costs and benefits. They must carefully address biases due to behavioral differences in those who chose to or were eligible to receive vaccines in real-world settings compared to those who did not. For example, vaccine recipients may be more cautious and have fewer possible exposures than individuals who chose not to be vaccinated; they may also be less cautious if they believe they are protected by vaccination. On the other hand, observational studies provide a more realistic picture of population heterogeneity compared to RCTs, and likely include populations of interest, like people who are immunocompromised. During massive national vaccination campaigns like those occurring for COVID-19, it is also possible to obtain much larger sample sizes from real-world observational studies, therefore arguably improving the precision of estimates for effectiveness, especially against severe outcomes.

\section{Sources of heterogeneity across studies}


COVID-19 vaccine studies were conducted by many independent research teams and in diverse epidemic settings around the world (Table 1, Table 2, Table S1, Figure 1). Consequently, there are several potential sources of heterogeneity between studies that make it difficult to compare VE estimates between them. These factors have been described elsewhere ${ }^{48,49}$ and include:

- Study population: When a study includes a greater number of participants who are at higher risk of developing symptomatic disease (e.g., older individuals) or with conditions that could reduce the immunogenicity of vaccines (e.g., people living with HIV), VE can be reduced.

- Outcome and case definition: VE values differ between disease outcomes with varying levels of severity. Even when studies have the same stated outcome, the case definition can vary substantially. For example, most clinical trials used 'symptomatic disease' with laboratory confirmed SARS-CoV-2 infection as the primary outcome but included anywhere from 5 (for AstraZeneca/AZD1222 ${ }^{50}$ ) to 16 (Janssen/Ad26.COV2.S ${ }^{36}$ ) different potential symptoms and varied in requiring one or two to be present. These differences are exacerbated in effectiveness studies that often rely on passive surveillance by health systems. In addition, differences in the timing included in the definition of the disease outcome (e.g., death within 30 days after diagnosis) can lead to heterogeneities.

- Follow-up period: Since it takes time after vaccination for an effective adaptive immune response to develop, studies that begin the estimation of VE sooner could observe reduced VE (e.g., 7+ days for Novavax/NVX-CoV2373 vs 28+ days for Janssen/Ad26.COV2.S). In addition, immune protection may eventually start to wane over time, and so studies that cover longer periods from time since vaccination could also lead to a lower VE.

- Predominant variants: Some SARS-CoV-2 variants of concern have been observed to exhibit immune-escape properties ${ }^{17}$ (e.g., Beta ${ }^{51-53}$ and Delta ${ }^{20,21,35}$ variants). Studies conducted when such variants account for a greater proportion of overall infections could result in lower observed vaccine efficacy (Figure 1).

- Force of infection: In studies done during time periods of higher prevalence of circulating virus (Figure 1), the number of exposures each individual experiences during the study period could be increased, which could make it more likely at least one exposure overwhelms vaccine-induced immunity and could lead to reduced observed VE, especially for vaccines that reduce per exposure risk (“leaky" vaccines) ${ }^{25,54}$.

- Study design and analysis: Randomization in vaccine trials can reduce (but not eliminate) confounding. In the absence of randomization, vaccine effectiveness studies can attempt to reduce confounding through study design (e.g., the test-negative design) and during the analysis (e.g., controlling for potential confounding variables in regression models). Some studies, especially those that use administrative data, may not collect and therefore control for such possible confounders.

\section{Results of COVID-19 vaccine studies}

As of August 15, 2021 there were 24 unique vaccine products that had entered the WHO Emergency Use Listing evaluation process, six of which had received authorization. The products under evaluation included mRNA, viral vector, inactivated virus, protein subunit, and conjugate vaccines, and were developed by a mix of pharmaceutical companies, non-profit research institutes, and government agencies (Table 1). Thirteen of these vaccine candidates completed Phase 3 clinical trials and released their VE estimates and uncertainty intervals publicly (Figure 2), which we collected via 21 separate reports ${ }^{22,35-44,50-52,55-60}$ (Figure S1). This included Oxford/AstraZeneca's AZD1222, Bharat Biotech's BBV152, BioCubaFarma's Abdala, Soberano 2, and Soberano 2 Plus, Gamaleya Institute's Sputnik V, 
Janssen's Ad26.COV2.S, Moderna's mRNA-1273, Pfizer/BioNTech's BNT162b2, Sinopharm Beijing's BBIBP-CorV, Sinopharm Wuhan's WIBP-CorV, and Sinovac's CoronaVac. Vaccine efficacy against symptomatic COVID-19, the primary outcome of each trial, ranged from 66-95\%. Vaccines with the highest reported efficacy included both first-in-class mRNA vaccines as well as protein subunit vaccines, a fifty year-old technology. Some of these clinical trials additionally reported efficacy against any infection or against more severe forms of disease (included in Figures 3-7, Table S1), though confidence intervals on the latter tended to be very large due to limited sample sizes and trial durations.

We identified a total of 58 real-world vaccine effectiveness studies covering five vaccines that met our inclusion criteria - BNT162b2 (Pfizer-BioNTech), mRNA-1273 (Moderna), Ad26.COV2.S (Janssen/Johnson \& Johnson), ChAdOx1 nCoV-19 (Oxford-AstraZeneca), and CoronaVac (Sinovac)

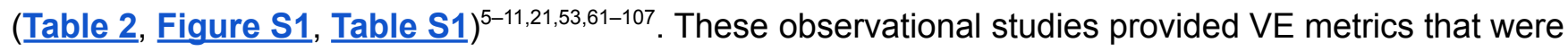
not available or estimated with high uncertainty in clinical trials, such as effectiveness against more severe outcomes, against any SARS-CoV-2 infection, against asymptomatic infection, against specific circulating SARS-CoV-2 variants of concern, and after only a single dose of two-dose vaccine courses (Figures 3-7). In general, effectiveness estimates were high for full vaccine courses and overlapped with efficacy values. Vaccines are more efficacious at preventing severe infection or death compared to symptomatic COVID-19. The degree to which the vaccine prevented any infection, and the degree to which partial courses prevented infection or disease, varied significantly by product. Data was especially sparse for VE against death or asymptomatic infection and against the Gamma (P.1) variant.

The most data was available for BNT162b2, the two-dose mRNA vaccine developed by Pfizer/BioNTech, mainly due to its use very early in 2021 in Israel, the UK, and the US (Figure 3). Overall VE estimates measured after both doses in the general population for all study types ranged from $90-100 \%$ for death, $85-98 \%$ for severe infection, $80-95 \%$ for symptomatic disease, $65-95 \%$ for any infection, and $65-90 \%$ for asymptomatic infection. These values were lower after only a single dose: $60-90 \%$ for severe infection, $30-90 \%$ for symptomatic disease, and $20-90 \%$ for any infection. Where comparisons were possible, effectiveness values from observational studies overlapped with efficacy estimates from clinical trials. Some studies found lower VE in special populations, including residents of long-term care facilities ${ }^{53,92}$ and the elderly ${ }^{91}$. Heterogeneities between studies made direct comparisons of $V E$ for variants of concern difficult. A few studies with head-to-head comparisons suggested reduced VE for BTN162b2 against the Beta (B.1.351) and Delta (B.1.617.2) compared to Alpha (B.1.1.7) variants of concern for symptomatic cases or any infection $20,21,61,89$.

The other authorized two-dose mRNA vaccine, Moderna's mRNA-1273, was also relatively well-studied based largely on data from the USA, Canada, and Qatar (Figure 4). After both doses, overall VE estimates in the general population fell between $90-96 \%$ for severe disease, $87-100 \%$ for symptomatic disease, $85-98 \%$ for any infection, and $92 \%$ for asymptomatic infection. With only a single dose VE values were $75-80 \%$ for severe disease, $55-92 \%$ for symptomatic disease, $30-90 \%$ for any infection, and $45-60 \%$ for asymptomatic infection. No studies that met our inclusion criteria reported VE against death. Studies in Qatar ${ }^{20,70}$ estimated VE for symptomatic infection with Delta after both doses compared to overall estimates or estimates for earlier variants (e.g. Alpha), and found reductions of $\sim 10 \%$. Similar reductions were not seen for VE against more severe outcomes or for the Alpha variant.

AstraZeneca's two-dose viral vector vaccine (AZD1222) was also the focus of many studies, especially after only a single dose, likely due to the fact that the recommended interval between doses is longer than other vaccines (12 weeks) and some countries including the UK and Canada adopted the strategy 
of prioritizing first doses over second doses in early 2021 (Figure 5). VE after both doses was 75-100\% for severe disease, $65-80 \%$ for symptomatic disease, $60-85 \%$ for any infection, and $15 \%$ for asymptomatic infection overall in the general population. After only a single dose, VE ranges were $85-95 \%$ for severe disease, $50-75 \%$ for symptomatic disease, and $0-95 \%$ for any infection. There was no evidence that the Alpha variant led to a reduction in VE for AZD1222, whereas the Delta variant appeared to lead to a 10-15\% reduction against symptomatic disease or infection after both doses and $\sim 20 \%$ after a single dose in some ${ }^{21,89}$ but not all ${ }^{93}$ studies. Evidence from the clinical trial site in South Africa ${ }^{51}$ suggested loss of efficacy against any symptomatic infection with the Beta variant, but with much uncertainty (VE $10 \% \mathrm{Cl}[<0,55])$.

Effectiveness studies of Sinovac's inactivated virus vaccine CoronaVac were only available from Chile ${ }^{85}$ and for individuals $>70$ years old in Brazil ${ }^{100}$, which complemented results from three separate clinical trials, including one restricted to health care workers (Figure 6). After both doses, in the general population, VE was $80-86 \%$ against death, $85-100 \%$ against severe disease, $65-85 \%$ against symptomatic disease, and $\sim 66 \%$ against any infection. With only one dose, these values were significantly reduced, to $40-46 \%$ for death, $37 \%$ for severe disease, and $16 \%$ for symptomatic disease and infection. No VE estimates for specific variants were available from any study, though the study in Brazil $^{100}$ was conducted during a time when Gamma (P.1) was predominant, which could in part explain - along with the older study population - the lower VE estimates in this study.

Data was similarly sparse for Janssen/Johnson \& Johnson's Ad26.COV2.S single-dose viral vector vaccine, with clinical trials providing the majority of data (Figure 7). Overall VE estimates were $100 \%$ against death, $85 \%$ for severe disease, $66 \%$ for symptomatic disease, $12-77 \%$ for any infection, and $65 \%$ for asymptomatic infection. VE against infection with the Beta (B.1.351) variant was not significantly reduced during the clinical trial in South Africa ${ }^{36}$.

Although at the time of writing there were at least 12 other COVID-19 vaccines that had received emergency authorization for widespread use in at least one country, we could not locate effectiveness studies meeting our inclusion criteria. This was especially notable for Gamaleya's Sputnik V and Sinopharm-Beijing's BBIBP-CorV, which have each been deployed in dozens of countries (Table 1).

\section{Discussion}

The development of COVID-19 vaccines has been an astounding feat of science. Within a year of detecting the first outbreak and isolating the SARS-CoV-2 virus, multiple vaccines were being deployed around the world. In this review, we systematically collected and reported efficacy and effectiveness ("VE") values by vaccine platform, disease outcome, number of doses, and SARS-CoV-2 variant. These findings demonstrated robust evidence for the high VE of COVID-19 vaccines both in clinical trials and real-world settings. We found that across all vaccine platforms, protection against severe infection or death in the general population was at least $80 \%$ and often close to $100 \%$. VE against symptomatic disease was heterogeneous between vaccine products and studies but was almost always greater than $65 \%$ and often greater than $90 \%$. The vast majority of studies showed that vaccines provided protection against infection itself - not just disease - demonstrating the potential for indirect protective effects (i.e., "herd immunity"). The degree of protection offered by only a single dose of two-dose vaccine courses varied by product. Most vaccines retained high levels of protection for most SARS-CoV-2 variants of concern, especially against severe outcomes. A few studies provided evidence of slight reductions in 
VE for infection or mild disease with the Beta (B.1.351) and Delta (B.1.617.2) strains. No studies meeting our inclusion criteria provided VE estimates for the Gamma (P.1) strain.

There are several important components of COVID-19 vaccine efficacy/effectiveness that we did not address in this study. Individuals previously infected with COVID-19 tend to have elevated levels of neutralizing antibodies ( $\mathrm{nAb}$ ) against SARS-CoV-2, and some studies have demonstrated that with only a single vaccine dose these individuals tend to reach similar nAb levels as individuals without a history of infection reach only after two doses ${ }^{108-110}$. Thus, VE could differ by serostatus. Some clinical trials excluded individuals seropositive at baseline and those that did not generally did not have enough power to test for differences in VE by serostatus at baseline. In Qatar, one observational study found that the vaccine effectiveness of BNT162b2 (Pfizer) was increased in individuals with a previous history of infection ${ }^{111}$, and another found that among unvaccinated persons, prior infection reduced the risk of new infection by $74 \%{ }^{112}$. Because infection results in natural immunity, including persons previously infected with SARS-CoV-2 in the unvaccinated group can bias estimates of VE downward. Of 58 observational studies included in this review, 19 included persons with previous SARS-CoV-2 infection.

Knowledge gained from studying vaccines for other pathogens in humans and animals shows that time may be an important dimension for vaccine efficacy. After vaccination (or infection), there is a necessary period during which antibody-producing plasma cells and their B cell precursors expand to levels necessary to reduce the risk of infection or disease after an exposure ${ }^{113}$. This interval is often estimated as around 2 weeks, which is why studies almost always count only cases after this time period when calculating $\mathrm{VE}^{29,114,115}$. However, protection can continue to increase for a few months, as suggested in the Janssen (Ad26.COV2.S) trial ${ }^{36}$. Over longer time periods, immune protection is maintained by long-lived plasma cells and memory $B$ and T cells, but numbers of these cells can decay over time, leading to waning in $\mathrm{VE}^{29,31,113,114,116}$. While most studies reviewed here were conducted in a short time period after vaccination ( $<6$ months) and did not examine waning, this is currently a critical issue for COVID-19 vaccines, and new studies will help address this question over the next year. Several recent reports have suggested reductions in VE over time ${ }^{16,41,117-120}$, while the WHO regards current evidence as inconclusive and stresses prioritization of primary doses ${ }^{121}$. Despite this, several governments have already begun administering additional "booster" doses (e.g., France ${ }^{122}$, Israel ${ }^{123}$ ), and others have announced tentative plans to do so in the future (e.g., US ${ }^{124}$ ).

For multi-dose vaccine regimens, the time interval between the initial dose and any follow up doses may affect the overall VE. While few clinical trials included variation in dose spacing, the trial of AZD1222 (AstraZeneca) varied the interval between doses and found that efficacy increased from $55 \%$ with less than 6 weeks between doses to $81 \%$ with more than 12 weeks ${ }^{50}$. In real-world settings, this interval often varied due to explicit policies of delaying second doses in favor of universal partial vaccination ${ }^{125,126}$, allowing for evaluation of its impact on both $\mathrm{nAb}$ levels and $\mathrm{VE}^{7,16,127}$. Currently, while most vaccine manufacturers and international advisory committees (including $\mathrm{WHO}^{128}$ ) recommend that initial and subsequent vaccine doses be with the same product - as this was the regimen tested in clinical trials - many countries have adopted more flexible policies allowing for "mixing and matching" of doses $^{129-131}$, often in response to supply constraints. In immunology, this strategy is termed "heterologous prime boost" 132 and has been explicitly investigated in vaccine studies as a way of enhancing the strength and breadth of immunity (e.g., for HIV ${ }^{133}$, influenza ${ }^{134}$, and Ebola ${ }^{135}$ ). Gamaleya's Sputnik $V$ vaccine uses two different modified adenoviruses to deliver the gene for the SARS-CoV-2 spike protein in the first (Ad26) vs second doses (Ad5) ${ }^{42}$. Preliminary studies have shown that boosting AstraZeneca's AZD1222 vaccine with Pfizer's BNT162b2 or Moderna's mRNA-1273 
increases nAb levels compared to two doses of AZD1222 alone ${ }^{136-140}$, and an observational study in Denmark found an effectiveness of $88 \%$ against SARS-CoV-2 infection for the combination of 1 dose of AZD1222 and a second dose of either mRNA vaccine ${ }^{80}$. Further work is needed to understand which vaccine combinations are safe and effective for COVID-19.

At an individual level, the goal of vaccination against COVID-19 is to prevent morbidity (e.g. symptoms, hospitalization, death), but from a population-level perspective, there is an additional goal of reducing transmission. The additional indirect protection offered by vaccines slows the spread of infection, and removes the need for complete vaccine coverage, which is currently a challenge as no vaccine is approved yet for use in children. For individuals who become infected with SARS-CoV-2 despite vaccination (i.e., "breakthrough" infection), an important additional efficacy metric is the reduction in their potential for transmission ${ }^{141}$. A few studies have estimated this reduction for COVID-19 by enrolling and testing close contacts of cases ${ }^{11,87,96,142-145}$. SARS-CoV-2 viral load in the respiratory tract is expected to be a determinant of transmission risk, and other studies have measured reductions in viral load in breakthrough (versus unvaccinated) $\operatorname{cases}^{16,101,107,146}$. The ability of COVID-19 vaccines to reduce transmission, especially in individuals with asymptomatic or mild infection, is expected to be especially important as vaccine access is expanded to children, in whom infection tends to be mild.

In conclusion, data from a wide variety of study types and settings demonstrate that COVID-19 vaccines provide high levels of protection against severe disease, and additionally protect against infection and mild disease, even for major SARS-CoV-2 variants of concern. 


\section{AUTHOR CONTRIBUTIONS}

ALH proposed the Review with input from BW, CBJ, JGR, MDK, MMH, and SAT. AAN, ALH, BW, CBJ, and JGR and conducted the search for clinical trials of COVID-19 vaccines and extracted efficacy values. $A B, P S Z, K W$ and $M M H$ conducted the search for observational studies of COVID-19 vaccines and extracted effectiveness values. MDK, DRF, and MKP supervised the collection of vaccine effectiveness studies including designing the search strategy, choosing the inclusion criteria, and evaluating studies against these criteria. ALH and $\mathrm{MMH}$ synthesized and interpreted the data on efficacy and effectiveness. BW assembled data on clinical trial timing, location, and SARS-CoV-2 variant prevalence. $\mathrm{ALH}, \mathrm{BW}$, and $\mathrm{MMH}$ created the tables and figures. $\mathrm{ALH}, \mathrm{CBJ}, \mathrm{BW}$, JGR and $\mathrm{MHH}$ drafted the manuscript. All authors revised the manuscript and approved it for submission.

\section{ACKNOWLEDGMENTS}

The authors thank M Kate Grabowski and the Johns Hopkins University Novel Coronavirus Research Compendium for bringing the study authors together to work on this paper. $\mathrm{MHH}, \mathrm{AB}, \mathrm{PS}, \mathrm{KW}$, and MDK received funding to collect the data used in work through a contract from the WHO to the International Vaccine Access Center at Johns Hopkins University. ALH and AAN received support from the US National Institutes of Health (NIH DP5OD019851). All other authors received no specific funding support for this work. The study sponsors had no role in the study design, in the collection, analysis, and interpretation of data, in the writing of the report, or in the decision to submit the paper for publication. The views represented in this article do not necessarily reflect the views of the WHO or the $\mathrm{NIH}$.

\section{DECLARATION OF INTERESTS}

Study authors have received grant funding from the Bill \& Melinda Gates Foundation (MMH, MDK, ALH, AAN), US National Institutes of Health (ALH), the US Centers for Disease Control and Prevention (SAT), and the US Department of Health and Human Services (ALH, SAT) for work unrelated to this project. CBJ and JGR received funding from the Novel Coronavirus Research Compendium at Johns Hopkins to conduct reviews of COVID-19 vaccine papers for other purposes. MMH and MDK have previously received support from a grant from Pfizer Inc to Johns Hopkins University for a non-COVID-19 vaccine. BW provided unpaid technical support to Bharat Biotech related to the clinical development of the BBV152 vaccine candidate. DRF previously served on an independent data monitoring committee for GlaxoSmithKline for a non-COVID-19 vaccine candidate. SAT served as an expert consultant for Milliman, Inc on future COVID-19 trajectories. All other authors declare no competing interests. 


\section{REFERENCES}

1 Cucinotta D, Vanelli M. WHO Declares COVID-19 a Pandemic. Acta Bio Medica Atenei Parm 2020; 91: 157-60.

2 Mathieu E, Ritchie H, Ortiz-Ospina E, et al. A global database of COVID-19 vaccinations. Nat Hum Behav 2021; 5: 947-53.

3 Basta N, Moodie E, McGill University COVID19 Vaccine Tracker Team. COVID-19 Vaccine Development and Approvals Tracker. COVID19 Vaccine Tracker. 2021; published online Aug 15. https://covid19.trackvaccines.org/ (accessed Aug 26, 2021).

4 Voysey M, Clemens SAC, Madhi SA, et al. Safety and efficacy of the ChAdOx1 nCoV-19 vaccine (AZD1222) against SARS-CoV-2: an interim analysis of four randomised controlled trials in Brazil, South Africa, and the UK. The Lancet 2021; 397: 99-111.

5 Stowe J, Andrews N, Gower C, et al. Effectiveness of COVID-19 vaccines against hospital admission with the Delta (B.1.617.2) variant. Public Health England, 2021

https://khub.net/documents/135939561/479607266/Effectiveness+of+COVID-19+vaccines+against+h ospital+admission+with+the+Delta+\%28B.1.617.2\%29+variant.pdf/1c213463-3997-ed16-2a6f-14e5de b0b997? $t=1623689315431$ (accessed June 22, 2021).

6 Whitaker HJ, Tsang RS, Byford R, et al. Pfizer-BioNTech and Oxford AstraZeneca COVID-19 vaccine effectiveness and immune response among individuals in clinical risk groups. Public Health England, 2021.

7 Amirthalingam G, Bernal JL, Andrews NJ, et al. Higher serological responses and increased vaccine effectiveness demonstrate the value of extended vaccine schedules in combatting COVID-19 in England. medRxiv 2021; : 2021.07.26.21261140.

8Public Health England3. COVID-19 vaccine surveillance report - week 20. PHE, 2021.

9 Vasileiou $\mathrm{E}$, Simpson CR, Shi T, et al. Interim findings from first-dose mass COVID-19 vaccination roll-out and COVID-19 hospital admissions in Scotland: a national prospective cohort study. The Lancet 2021; 397: 1646-57.

10 Hitchings MDT, Ranzani OT, Dorion M, et al. Effectiveness of the ChAdOx1 vaccine in the elderly during SARS-CoV-2 Gamma variant transmission in Brazil. medRxiv 2021; : 2021.07.19.21260802.

11 de Gier B, Andeweg S, Joosten R, et al. Vaccine effectiveness against SARS-CoV-2 transmission and infections among household and other close contacts of confirmed cases, the Netherlands, February to May 2021. Eurosurveillance 2021; 26: 2100640.

12 Kissler SM, Fauver JR, Mack C, et al. Viral dynamics of SARS-CoV-2 variants in vaccinated and unvaccinated individuals. 2021; : 2021.02.16.21251535.

13 Kang M, Xin H, Yuan J, et al. Transmission dynamics and epidemiological characteristics of Delta variant infections in China. 2021.

14 Li B, Deng A, Li K, et al. Viral infection and transmission in a large, well-traced outbreak caused by the SARS-CoV-2 Delta variant. 2021.

15 Luo $\mathrm{CH}$, Morris CP, Sachithanandham J, et al. Infection with the SARS-CoV-2 Delta Variant is Associated with Higher Infectious Virus Loads Compared to the Alpha Variant in both Unvaccinated and Vaccinated Individuals. 2021.

16 Pouwels KB, Pritchard E, Matthews PC, et al. Impact of Delta on viral burden and vaccine effectiveness against new SARS-CoV-2 infections in the UK. 2021; : 2021.08.18.21262237.

17 WHO. Weekly epidemiological update on COVID-19 - 24 August 2021. Geneva, Switzerland: World Health Organization, 2021 https://www.who.int/publications/m/item/weekly-epidemiological-update-on-covid-19---24-august-2021 (accessed Aug 26, 2021).

18 Garcia V, Feldman MW. Within-Epitope Interactions Can Bias CTL Escape Estimation in Early HIV Infection. Front Immunol 2017; 8. DOI:10.3389/fimmu.2017.00423.

19 CDC. SARS-CoV-2 Variant Classifications and Definitions. Coronavirus Dis. 2019 COVID-19. 2020; published online Feb 11. https://www.cdc.gov/coronavirus/2019-ncov/variants/variant-info.html (accessed Aug 26, 2021). 
20 Tang P, Hasan MR, Chemaitelly $\mathrm{H}$, et al. BNT162b2 and mRNA-1273 COVID-19 vaccine effectiveness against the Delta (B.1.617.2) variant in Qatar. medRxiv 2021; : 2021.08.11.21261885.

21 Sheikh A, McMenamin J, Taylor B, Robertson C. SARS-CoV-2 Delta VOC in Scotland: demographics, risk of hospital admission, and vaccine effectiveness. The Lancet 2021; 0 . DOI:10.1016/S0140-6736(21)01358-1.

22 Polack FP, Thomas SJ, Kitchin N, et al. Safety and Efficacy of the BNT162b2 mRNA Covid-19 Vaccine. N Engl J Med 2020; 383: 2603-15.

23 World Health Organization. Status of COVID-19 Vaccines within WHO EUL/PQ evaluation process. 2021; published online Aug 19.

https://extranet.who.int/pqweb/key-resources/documents/status-covid-19-vaccines-within-who-eulpq-e valuation-process (accessed Aug 26, 2021).

24 Halloran ME, Longini IM Jr, Struchiner CJ. Design and Interpretation of Vaccine Field Studies. Epidemiol Rev 1999; 21: 73-88.

25 Crowcroft NS, Klein NP. A framework for research on vaccine effectiveness. Vaccine 2018; 36: 7286-93.

26 Smith PG, Rodrigues LC, Fine PEM. Assessment of the Protective Efficacy of Vaccines against Common Diseases Using Case-Control and Cohort Studies. Int J Epidemiol 1984; 13: 87-93.

27 WHO D of I Vaccines and Biologicals. Correlates of vaccine-induced protection: methods and implications. Geneva, Switzerland: World Health Organization, 2013.

28 Leshem E, Lopman BA. Population immunity and vaccine protection against infection. The Lancet 2021; 397: 1685-7.

29 Kim DS, Rowland-Jones S, Gea-Mallorquí E. Will SARS-CoV-2 Infection Elicit Long-Lasting Protective or Sterilising Immunity? Implications for Vaccine Strategies (2020). Front Immunol 2020; 11: 3190 .

30 Hodgson SH, Mansatta K, Mallett G, Harris V, Emary KRW, Pollard AJ. What defines an efficacious COVID-19 vaccine? A review of the challenges assessing the clinical efficacy of vaccines against SARS-CoV-2. Lancet Infect Dis 2021; 21: e26-35.

31 Pollard AJ, Bijker EM. A guide to vaccinology: from basic principles to new developments. Nat Rev Immunol 2021; 21: 83-100.

32 Levin AT, Hanage WP, Owusu-Boaitey N, Cochran KB, Walsh SP, Meyerowitz-Katz G.

Assessing the age specificity of infection fatality rates for COVID-19: systematic review, meta-analysis, and public policy implications. Eur J Epidemiol 2020; 35: 1123-38.

33 Palmer S, Cunniffe N, Donnelly R. COVID-19 hospitalization rates rise exponentially with age, inversely proportional to thymic T-cell production. J R Soc Interface; 18: 20200982.

34 O'Driscoll M, Ribeiro Dos Santos G, Wang L, et al. Age-specific mortality and immunity patterns of SARS-CoV-2. Nature 2021; 590: 140-5.

35 Ella R, Reddy S, Blackwelder W, et al. Efficacy, safety, and lot to lot immunogenicity of an inactivated SARS-CoV-2 vaccine (BBV152): a, double-blind, randomised, controlled phase 3 trial. medRxiv 2021; : 2021.06.30.21259439.

36 Sadoff J, Gray G, Vandebosch A, et al. Safety and Efficacy of Single-Dose Ad26.COV2.S Vaccine against Covid-19. N Engl J Med 2021; published online April 21.

DOI:10.1056/NEJMoa2101544.

37 Baden LR, El Sahly HM, Essink B, et al. Efficacy and Safety of the mRNA-1273 SARS-CoV-2 Vaccine. N Engl J Med 2021; 384: 403-16.

38 AstraZeneca. AZD1222 US Phase III primary analysis confirms safety and efficacy. 2021; published online March 25.

https://www.astrazeneca.com/media-centre/press-releases/2021/azd1222-us-phase-iii-primary-analysi s-confirms-safety-and-efficacy.html (accessed April 19, 2021).

39 Novavax. Novavax COVID-19 Vaccine Demonstrates 90\% Overall Efficacy and 100\% Protection Against Moderate and Severe Disease in PREVENT-19 Phase 3 Trial - Jun 14, 2021. Novavax. 2021; published online June 14.

https://ir.novavax.com/2021-06-14-Novavax-COVID-19-Vaccine-Demonstrates-90-Overall-Efficacy-an d-100-Protection-Against-Moderate-and-Severe-Disease-in-PREVENT-19-Phase-3-Trial (accessed July 20, 2021). 
40 Heath PT, Galiza EP, Baxter DN, et al. Safety and Efficacy of NVX-CoV2373 Covid-19 Vaccine. N Engl J Med 2021; 0: null.

41 Thomas SJ, Moreira ED, Kitchin N, et al. Six Month Safety and Efficacy of the BNT162b2 mRNA COVID-19 Vaccine. 2021.

42 Logunov DY, Dolzhikova IV, Shcheblyakov DV, et al. Safety and efficacy of an rAd26 and rAd5 vector-based heterologous prime-boost COVID-19 vaccine: an interim analysis of a randomised controlled phase 3 trial in Russia. The Lancet 2021; 397: 671-81.

43 Tanriover MD, Doğanay HL, Akova M, et al. Efficacy and safety of an inactivated whole-virion SARS-CoV-2 vaccine (CoronaVac): interim results of a double-blind, randomised, placebo-controlled, phase 3 trial in Turkey. The Lancet 2021; 398: 213-22.

44 Palacios R, Batista AP, Albuquerque CSN, et al. Efficacy and Safety of a COVID-19 Inactivated Vaccine in Healthcare Professionals in Brazil: The PROFISCOV Study. Rochester, NY: Social Science Research Network, 2021 DOI:10.2139/ssrn.3822780.

45 Weinberg GA, Szilagyi PG. Vaccine Epidemiology: Efficacy, Effectiveness, and the Translational Research Roadmap. J Infect Dis 2010; 201: 1607-10.

46 WHO. Vaccine efficacy, effectiveness and protection. World Health Organ. 2021; published online July 14.

https://www.who.int/news-room/feature-stories/detail/vaccine-efficacy-effectiveness-and-protection (accessed Aug 27, 2021).

47 Patel MK, Bergeri I, Bresee JS, et al. Evaluation of post-introduction COVID-19 vaccine effectiveness: Summary of interim guidance of the World Health Organization. Vaccine 2021; 39: 4013-24.

48 WHO. Evaluation of COVID-19 vaccine effectiveness: Interm Guidance. Geneva, Switzerland: World Health Organization, 2021

https://www.who.int/publications-detail-redirect/WHO-2019-nCoV-vaccine_effectiveness-measurement -2021.1 (accessed Aug 27, 2021).

49 Rapaka RR, Hammershaimb EA, Neuzil KM. Are some COVID vaccines better than others? Interpreting and comparing estimates of efficacy in trials of COVID-19 vaccines. Clin Infect Dis 2021; : ciab213.

50 Voysey M, Clemens SAC, Madhi SA, et al. Single-dose administration and the influence of the timing of the booster dose on immunogenicity and efficacy of ChAdOx1 nCoV-19 (AZD1222) vaccine: a pooled analysis of four randomised trials. The Lancet 2021; 397: 881-91.

51 Madhi SA, Baillie V, Cutland CL, et al. Efficacy of the ChAdOx1 nCoV-19 Covid-19 Vaccine against the B.1.351 Variant. N Engl J Med 2021; published online March 16.

DOI:10.1056/NEJMoa2102214.

52 Shinde V, Bhikha S, Hoosain Z, et al. Efficacy of NVX-CoV2373 Covid-19 Vaccine against the B.1.351 Variant. N Engl J Med 2021; 384: 1899-909.

53 Lefèvre B, Tondeur L, Madec Y, et al. Impact of B.1.351 (beta) SARS-CoV-2 variant on BNT162b2 mRNA vaccine effectiveness in long-term care facilities of eastern France: a retrospective cohort study. medRxiv 2021; : 2021.07.28.21261285.

54 Edlefsen PT. Leaky vaccines protect highly exposed recipients at a lower rate: implications for vaccine efficacy estimation and sieve analysis. Comput Math Methods Med 2014; 2014: 813789.

55 Emary KRW, Golubchik T, Aley PK, et al. Efficacy of ChAdOx1 nCoV-19 (AZD1222) vaccine against SARS-CoV-2 variant of concern 202012/01 (B.1.1.7): an exploratory analysis of a randomised controlled trial. The Lancet 2021; 397: 1351-62.

56 Skowronski DM, De Serres G. Safety and Efficacy of the BNT162b2 mRNA Covid-19 Vaccine. N Engl J Med 2021; published online Feb 17. DOI:10.1056/NEJMc2036242.

57 Al Kaabi N, Zhang Y, Xia S, et al. Effect of 2 Inactivated SARS-CoV-2 Vaccines on Symptomatic COVID-19 Infection in Adults: A Randomized Clinical Trial. JAMA 2021; published online May 26. DOI:10.1001/jama.2021.8565.

58 Soeriaatmadja W. Indonesia grants emergency approval for Sinovac vaccine. Straits Times. 2021; published online Jan 12.

https://www.straitstimes.com/asia/se-asia/indonesia-grants-emergency-approval-for-sinovac-vaccine (accessed July 21, 2021). 
59 Finlay Vaccine Institute - Information Center. Interim clinical efficacy analysis of the heterologous dose schedule of SOBERANA02 and a booster dose of SOBERANA-Plus. Final results of the clinical efficacy of the two-dose schedule of SOBERANA02. Blog - Finlay Vaccine Inst. 2021; published online July 9.

http://www.finlay.edu.cu/blog/analisis-interino-de-eficacia-clinica-del-esquema-heterologo-de-dosis-de -soberana02-y-una-dosis-de-refuerzo-de-soberana-plus-resultados-finales-de-la-eficacia-clinica-del-e squema-de-dos-dosis-de-sobe/ (accessed Aug 2, 2021).

60 Caraballosa E. How was the efficacy of the Cuban COVID-19 vaccine candidates calculated? OnCuba News Engl. 2021; published online June 27.

https://oncubanews.com/en/cuba/how-was-the-efficacy-of-the-cuban-covid-19-vaccine-candidates-cal culated/ (accessed Aug 2, 2021).

61 Abu-Raddad LJ, Chemaitelly H, Butt AA. Effectiveness of the BNT162b2 Covid-19 Vaccine against the B.1.1.7 and B.1.351 Variants. N Engl J Med 2021; 0: null.

62 Alali WQ, Ali LA, AISeaidan M, Al-Rashidi M. Effectiveness of BNT162b2 and ChAdOx1 vaccines against symptomatic COVID-19 among Healthcare Workers in Kuwait: A retrospective cohort study. medRxiv 2021; published online July. DOI:10.1101/2021.07.25.21261083.

63 Andrejko KL, Pry J, Myers JF, et al. Prevention of COVID-19 by mRNA-based vaccines within the general population of California. Clin Infect Dis 2021; published online July.

DOI:10.1093/cid/ciab640.

64 Angel Y, Spitzer A, Henig O, et al. Association Between Vaccination With BNT162b2 and Incidence of Symptomatic and Asymptomatic SARS-CoV-2 Infections Among Health Care Workers. JAMA 2021; 325: 2457-65.

65 Azamgarhi T, Hodgkinson M, Shah A, et al. BNT162b2 vaccine uptake and effectiveness in UK healthcare workers - a single centre cohort study. Nat Commun 2021; 12: 3698.

66 Baum U, Poukka E, Palmu AA, Salo H, Lehtonen TO, Leino T. Effectiveness of vaccination against SARS-CoV-2 infection and Covid-19 hospitalization among Finnish elderly and chronically ill An interim analysis of a nationwide cohort study. medRxiv $2021 ;: 2021.06 .21 .21258686$.

67 Björk J, Inghammar M, Moghaddassi M, Rasmussen M, Malmqvist U, Kahn F. Effectiveness of the BNT162b2 vaccine in preventing COVID-19 in the working age population - first results from a cohort study in Southern Sweden. medRxiv 2021; : 2021.04.20.21254636.

68 Butt AA, Omer SB, Yan P, Shaikh OS, Mayr FB. SARS-CoV-2 Vaccine Effectiveness in a High-Risk National Population in a Real-World Setting. Ann Intern Med 2021; published online July 20. DOI:10.7326/M21-1577.

69 Carazo S, Talbot D, Boulianne N, et al. Single-dose mRNA vaccine effectiveness against SARS-CoV-2 in healthcare workers extending 16 weeks post-vaccination: a test-negative design from Quebec, Canada. Clin Infect Dis 2021; published online Aug. DOI:10.1093/cid/ciab739.

70 Chemaitelly $\mathrm{H}$, Yassine HM, Benslimane FM, et al. mRNA-1273 COVID-19 vaccine effectiveness against the B.1.1.7 and B.1.351 variants and severe COVID-19 disease in Qatar. Nat Med 2021; : 1-8.

71 Chung $\mathrm{H}$, He S, Nasreen S, et al. Effectiveness of BNT162b2 and mRNA-1273 covid-19 vaccines against symptomatic SARS-CoV-2 infection and severe covid-19 outcomes in Ontario, Canada: test negative design study. BMJ 2021; 374: $\mathrm{n} 1943$.

72 Corchado-Garcia J, Puyraimond-Zemmour D, Hughes T, et al. Real-world effectiveness of Ad26.COV2.S adenoviral vector vaccine for COVID-19. medRxiv 2021; : 2021.04.27.21256193.

73 Dagan1 N, Barda N, Kepten E, et al. BNT162b2 mRNA Covid-19 Vaccine in a Nationwide Mass Vaccination Setting. N Engl J Med 2021; published online Feb 24. DOI:10.1056/NEJMoa2101765.

74 Dagan2 N, Barda N, Biron-Shental T, et al. Effectiveness of the BNT162b2 mRNA COVID-19 vaccine in pregnancy. Nat Med 2021; : 1-3.

75 Emborg H-D, Valentiner-Branth P, Schelde AB, et al. Vaccine effectiveness of the BNT162b2 mRNA COVID-19 vaccine against RT-PCR confirmed SARS-CoV-2 infections, hospitalisations and mortality in prioritised risk groups. medRxiv 2021; : 2021.05.27.21257583.

76 Fabiani M, Ramigni M, Gobbetto V, Mateo-Urdiales A, Pezzotti P, Piovesan C. Effectiveness of the Comirnaty (BNT162b2, BioNTech/Pfizer) vaccine in preventing SARS-CoV-2 infection among healthcare workers, Treviso province, Veneto region, Italy, 27 December 2020 to 24 March 2021. 
Eurosurveillance 2021; 26: 2100420.

77 Flacco ME, Soldato G, Acuti Martellucci C, et al. Interim Estimates of COVID-19 Vaccine Effectiveness in a Mass Vaccination Setting: Data from an Italian Province. Vaccines 2021; 9: 628.

78 Glampson B, Brittain J, Kaura A, et al. North West London Covid-19 Vaccination Programme: Real-world evidence for Vaccine uptake and effectiveness: Retrospective Cohort Study. JMIR Public Health Surveill 2021; published online July. DOI:10.2196/30010.

79 Goldberg Y, Mandel M, Woodbridge Y, et al. Protection of previous SARS-CoV-2 infection is similar to that of BNT162b2 vaccine protection: A three-month nationwide experience from Israel. medRxiv 2021; : 2021.04.20.21255670.

80 Gram MA, Nielsen J, Schelde AB, et al. Vaccine effectiveness when combining the ChAdOx1 vaccine as the first dose with an mRNA COVID-19 vaccine as the second dose. medRxiv 2021; : 2021.07.26.21261130.

81 Gras-Valentí P, Chico-Sánchez P, Algado-Sellés N, et al. Effectiveness of the first dose of BNT162b2 vaccine to preventing covid-19 in healthcare personnel. Rev Esp Salud Publica 2021; 95 : e202104070.

82 Haas EJ, Angulo FJ, McLaughlin JM, et al. Impact and effectiveness of mRNA BNT162b2 vaccine against SARS-CoV-2 infections and COVID-19 cases, hospitalisations, and deaths following a nationwide vaccination campaign in Israel: an observational study using national surveillance data. The Lancet 2021; 397: 1819-29.

83 Hyams C, Marlow R, Maseko Z, et al. Effectiveness of BNT162b2 and ChAdOx1 nCoV-19 COVID-19 vaccination at preventing hospitalisations in people aged at least 80 years: a test-negative, case-control study. Lancet Infect Dis 2021; 0. DOI:10.1016/S1473-3099(21)00330-3.

84 Ismail SA, Vilaplana TG, Elgohari S, et al. Effectiveness of BNT162b2 mRNA and ChAdOx1 adenovirus vector COVID-19 vaccines on risk of hospitalisation among older adults in England: an observational study using surveillance data. Public Health England, 2021.

85 Jara A, Undurraga EA, González C, et al. Effectiveness of an Inactivated SARS-CoV-2 Vaccine in Chile. N Engl J Med 2021; 385: 875-84.

$86 \quad$ Kissling E, Hooiveld M, Martín VS, et al. Vaccine effectiveness against symptomatic

SARS-CoV-2 infection in adults aged 65 years and older in primary care: I-MOVE-COVID-19 project, Europe, December 2020 to May 2021. Eurosurveillance 2021; 26: 2100670.

87 Layan M, Gilboa M, Gonen T, et al. Impact of BNT162b2 vaccination and isolation on SARS-CoV-2 transmission in Israeli households: an observational study. medRxiv 2021; : 2021.07.12.21260377.

88 Lopez Bernal1 J, Andrews N, Gower C, et al. Effectiveness of the Pfizer-BioNTech and Oxford-AstraZeneca vaccines on covid-19 related symptoms, hospital admissions, and mortality in older adults in England: test negative case-control study. BMJ 2021; 373: n1088.

89 Lopez Bernal2 J, Andrews N, Gower C, et al. Effectiveness of Covid-19 Vaccines against the B.1.617.2 (Delta) Variant. N Engl J Med 2021; published online July. DOI:10.1056/NEJMoa2108891.

90 Martínez-Baz I, Miqueleiz A, Casado I, et al. Effectiveness of COVID-19 vaccines in preventing SARS-CoV-2 infection and hospitalisation, Navarre, Spain, January to April 2021. Eurosurveillance 2021; 26: 2100438.

91 Mason T, Whitston M, Hodgson J, et al. Effects of BNT162b2 mRNA vaccine on Covid-19 infection and hospitalisation among older people: matched case control study for England. medRxiv 2021; : 2021.04.19.21255461.

92 Moustsen-Helms IR, Emborg H-D, Nielsen J, et al. Vaccine effectiveness after 1st and 2nd dose of the BNT162b2 mRNA Covid-19 Vaccine in long-term care facility residents and healthcare workers - a Danish cohort study. medRxiv 2021; : 2021.03.08.21252200.

93 Nasreen S, Chung H, He S, et al. Effectiveness of COVID-19 vaccines against variants of concern in Ontario, Canada. medRxiv 2021; : 2021.06.28.21259420.

94 Pawlowski C, Lenehan P, Puranik A, et al. FDA-authorized mRNA COVID-19 vaccines are effective per real-world evidence synthesized across a multi-state health system. Med 2021; 2: 979-992.e8.

95 Pritchard E, Matthews PC, Stoesser N, et al. Impact of vaccination on new SARS-CoV-2 infections in the United Kingdom. Nat Med 2021; 27: 1370-8. 
96 Prunas O, Warren JL, Crawford FW, et al. Vaccination with BNT162b2 reduces transmission of SARS-CoV-2 to household contacts in Israel. medRxiv 2021; : 2021.07.13.21260393.

97 Public Health England1. PHE monitoring of the early impact and effectiveness of COVID-19 vaccination in England. PHE, 2021 https://assets.publishing.service.gov.uk/government/uploads/system/uploads/attachment_data/file/968 977/COVID-19_vaccine_effectiveness_surveillance_report_February_2021.pdf (accessed Sept 13, 2021).

98 Public Health England2. Public Health England vaccine effectiveness report. PHE, 2021.

99 Puranik A, Lenehan PJ, Silvert E, et al. Comparison of two highly-effective mRNA vaccines for COVID-19 during periods of Alpha and Delta variant prevalence. medRxiv 2021; :

2021.08.06.21261707.

100 Ranzani OT, Hitchings M, Dorion M, et al. Effectiveness of the CoronaVac vaccine in the elderly population during a P.1 variant-associated epidemic of COVID-19 in Brazil: A test-negative case-control study. medRxiv 2021; : 2021.05.19.21257472.

101 Regev-Yochay G, Amit S, Bergwerk M, et al. Decreased infectivity following BNT162b2 vaccination: A prospective cohort study in Israel. Lancet Reg Health Eur 2021; 7: 100150.

102 Saciuk Y, Kertes J, Mandel M, Hemo B, Shamir Stein N, Zohar AE. Pfizer-BioNTech Vaccine Effectiveness Against SARS-CoV-2 Infection: Findings From a Large Observational Study in Israel. Rochester, NY: Social Science Research Network, 2021 DOI:10.2139/ssrn.3868853.

103 Shrotri M, Krutikov M, Palmer T, et al. Vaccine effectiveness of the first dose of ChAdOx1 nCoV-19 and BNT162b2 against SARS-CoV-2 infection in residents of long-term care facilities in England (VIVALDI): a prospective cohort study. Lancet Infect Dis 2021; 0.

DOI:10.1016/S1473-3099(21)00289-9.

104 Skowronski DM, Setayeshgar S, Zou M, et al. Single-dose mRNA vaccine effectiveness against SARS-CoV-2, including P.1 and B.1.1.7 variants: a test-negative design in adults 70 years and older in British Columbia, Canada. medRxiv 2021; : 2021.06.07.21258332.

105 Tande AJ, Pollock BD, Shah ND, et al. Impact of the Coronavirus Disease 2019 (COVID-19) Vaccine on Asymptomatic Infection Among Patients Undergoing Preprocedural COVID-19 Molecular Screening. Clin Infect Dis 2021; published online March. DOI:10.1093/cid/ciab229.

106 Tenforde MW, Billig Rose E, Lindsell CJ, et al. Characteristics of Adult Outpatients and Inpatients with COVID-19 - 11 Academic Medical Centers, United States, March-May 2020. MMWR Morb Mortal Wkly Rep 2020; 69: 841-6.

107 Thompson MG, Burgess JL, Naleway AL, et al. Prevention and Attenuation of Covid-19 with the BNT162b2 and mRNA-1273 Vaccines. N Engl J Med 2021; 385: 320-9.

108 Krammer F, Srivastava K, Alshammary H, et al. Antibody Responses in Seropositive Persons after a Single Dose of SARS-CoV-2 mRNA Vaccine. N Engl J Med 2021; 384: 1372-4.

109 Anichini G, Terrosi C, Gandolfo C, et al. SARS-CoV-2 Antibody Response in Persons with Past Natural Infection. N Engl J Med 2021; 0: null.

110 Manisty C, Otter AD, Treibel TA, et al. Antibody response to first BNT162b2 dose in previously SARS-CoV-2-infected individuals. The Lancet 2021; 397: 1057-8.

111 Abu-Raddad LJ, Chemaitelly $\mathrm{H}$, Ayoub $\mathrm{HH}$, et al. Protection afforded by the BNT162b2 and mRNA-1273 COVID-19 vaccines in fully vaccinated cohorts with and without prior infection. medRxiv 2021; : 2021.07.25.21261093.

112 Bertollini R, Chemaitelly H, Yassine HM, Al-Thani MH, Al-Khal A, Abu-Raddad LJ. Associations of Vaccination and of Prior Infection With Positive PCR Test Results for SARS-CoV-2 in Airline Passengers Arriving in Qatar. JAMA 2021; 326: 185-8.

113 Murphy KM, Weaver C. Janeway's Immunobiology, Ninth edition. New York, NY: W. W. Norton \& Company, 2016.

114 Poland GA, Ovsyannikova IG, Kennedy RB. SARS-CoV-2 immunity: review and applications to phase 3 vaccine candidates. The Lancet 2020; 396: 1595-606.

115 Wei J, Stoesser N, Matthews PC, et al. Antibody responses to SARS-CoV-2 vaccines in 45,965 adults from the general population of the United Kingdom. Nat Microbiol 2021; 6: 1140-9.

116 Dan JM, Mateus J, Kato Y, et al. Immunological memory to SARS-CoV-2 assessed for up to 8 months after infection. Science 2021; published online Jan 6. DOI:10.1126/science.abf4063. 
117 Nanduri S. Effectiveness of Pfizer-BioNTech and Moderna Vaccines in Preventing SARS-CoV-2 Infection Among Nursing Home Residents Before and During Widespread Circulation of the SARS-CoV-2 B.1.617.2 (Delta) Variant - National Healthcare Safety Network, March 1-August 1, 2021. MMWR Morb Mortal Wkly Rep 2021; 70. DOI:10.15585/mmwr.mm7034e3.

118 Rosenberg ES. New COVID-19 Cases and Hospitalizations Among Adults, by Vaccination Status - New York, May 3-July 25, 2021. MMWR Morb Mortal Wkly Rep 2021; 70.

DOI:10.15585/mmwr.mm7034e1.

119 Israel A, Merzon E, Schäffer AA, et al. Elapsed time since BNT162b2 vaccine and risk of SARS-CoV-2 infection in a large cohort. 2021.

120 Mizrahi B, Lotan R, Kalkstein N, et al. Correlation of SARS-CoV-2 Breakthrough Infections to Time-from-vaccine; Preliminary Study. 2021.

121 WHO. Interim statement on COVID-19 vaccine booster doses. World Health Organ. 2021; published online Aug 10.

https://www.who.int/news/item/10-08-2021-interim-statement-on-covid-19-vaccine-booster-doses (accessed Aug 28, 2021).

122 Turnbull A, Corbet S. France first big EU nation to start widespread booster jabs. Assoc. Press. 2021; published online Sept 1.

https://apnews.com/article/europe-health-france-coronavirus-pandemic-coronavirus-vaccine-5c89993 c0c81d0e0ae2fa056ad9db0d7 (accessed Sept 5, 2021).

123 Staff. Israel widens 3rd COVID booster shot to those aged 12 and over. Times Isr. 2021;

published online Aug 29.

https://www.timesofisrael.com/israel-offers-covid-booster-shot-to-all-eligible-for-vaccine/ (accessed Sept 5, 2021).

124 Walensky R, Woodstock J, Murthy V, et al. Joint Statement from HHS Public Health and Medical Experts on COVID-19 Booster Shots. 2021; published online Aug 18.

https://www.cdc.gov/media/releases/2021/s0818-covid-19-booster-shots.html (accessed Aug 28, 2021).

125 Fay Cortez M. Delayed Second Dose Turns Into a Win for Vaccine-Starved Places.

Bloomberg.com. 2021; published online May 20.

https://www.bloomberg.com/news/articles/2021-05-20/delayed-second-dose-turns-into-a-win-for-vacci ne-starved-places (accessed Aug 26, 2021).

126 Wu KJ, Robbins R. In Europe, more countries delay second vaccine doses or mull plans to do so. N. Y. Times. 2021; published online Jan 4.

https://www.nytimes.com/2021/01/04/world/second-covid-vaccine-delay.html (accessed Aug 26, 2021).

127 Payne RP, Longet S, Austin JA, et al. Sustained T Cell Immunity, Protection and Boosting Using Extended Dosing Intervals of BNT162b2 mRNA Vaccine. Rochester, NY: Social Science Research Network, 2021 DOI:10.2139/ssrn.3891065.

128 World Health Organization. Interim statement on heterologous priming for COVID-19 vaccines. 2021; published online Aug 10.

https://www.who.int/news/item/10-08-2021-interim-statement-on-heterologous-priming-for-covid-19-va ccines (accessed Aug 26, 2021).

129 Lewis D. Mix-and-match COVID vaccines: the case is growing, but questions remain. Nature 2021; 595: 344-5.

130 Cunningham E. Covid-19 global updates: Some countries defend mixing vaccines after WHO suggests booster strategy is 'chaotic'. Wash. Post. 2021; published online July 14.

https://www.washingtonpost.com/world/2021/07/14/coronavirus-latest-updates/ (accessed Aug 26, 2021).

131 Anthes E. Why More People Are Getting Two Different Coronavirus Vaccines. N. Y. Times.

2021; published online June 24.

https://www.nytimes.com/2021/06/24/world/europe/covid-vaccine-mix-and-match-pfizer-moderna.html (accessed Aug 26, 2021).

132 Lu S. Heterologous Prime-Boost Vaccination. Curr Opin Immunol 2009; 21: 346-51.

133 Rerks-Ngarm S, Pitisuttithum P, Nitayaphan S, et al. Vaccination with ALVAC and AIDSVAX to 
medRxiv preprint doi: https://doi.org/10.1101/2021.09.17.21263549; this version posted September 25, 2021. The copyright holder for this preprint (which was not certified by peer review) is the author/funder, who has granted medRxiv a license to display the preprint in perpetuity.

It is made available under a CC-BY 4.0 International license .

Prevent HIV-1 Infection in Thailand. N Engl J Med 2009; 361: 2209-20.

134 Nolan T, Izurieta P, Lee B-W, et al. Heterologous Prime-Boost Vaccination Using an AS03B-Adjuvanted Influenza A(H5N1) Vaccine in Infants and Children $<3$ Years of Age. J Infect Dis 2014; 210: 1800-10.

135 Venkatraman N, Ndiaye BP, Bowyer G, et al. Safety and Immunogenicity of a Heterologous Prime-Boost Ebola Virus Vaccine Regimen in Healthy Adults in the United Kingdom and Senegal. $J$ Infect Dis 2019; 219: 1187-97.

136 Barros-Martins J, Hammerschmidt SI, Cossmann A, et al. Immune responses against SARS-CoV-2 variants after heterologous and homologous ChAdOx1 nCoV-19/BNT162b2 vaccination. Nat Med 2021; : 1-5.

137 Hillus D, Schwarz T, Tober-Lau P, et al. Safety, reactogenicity, and immunogenicity of homologous and heterologous prime-boost immunisation with ChAdOx1 nCoV-19 and BNT162b2: a prospective cohort study. Lancet Respir Med 2021; 0. DOI:10.1016/S2213-2600(21)00357-X.

138 Liu X, Shaw RH, Stuart ASV, et al. Safety and immunogenicity of heterologous versus homologous prime-boost schedules with an adenoviral vectored and mRNA COVID-19 vaccine (Com-COV): a single-blind, randomised, non-inferiority trial. The Lancet 2021; 0.

DOI:10.1016/S0140-6736(21)01694-9.

139 Schmidt T, Klemis V, Schub D, et al. Immunogenicity and reactogenicity of heterologous ChAdOx1 nCoV-19/mRNA vaccination. Nat Med 2021; : 1-6.

140 Normark J, Vikström L, Gwon Y-D, et al. Heterologous ChAdOx1 nCoV-19 and mRNA-1273 Vaccination. N Engl J Med 2021; 0: null.

141 Lipsitch M, Kahn R. Interpreting vaccine efficacy trial results for infection and transmission. Vaccine 2021; 39: 4082-8.

142 Harris RJ, Hall JA, Zaidi A, Andrews NJ, Dunbar JK, Dabrera G. Effect of Vaccination on Household Transmission of SARS-CoV-2 in England. N Engl J Med 2021; 385: 759-60.

143 Egunsola O, Mastikhina L, Dowsett L, et al. Transmissibility of COVID-19 among Vaccinated Individuals: A Rapid Literature Review - Update \#1. 2021.

144 Salo J, Hägg M, Kortelainen M, et al. The indirect effect of mRNA-based Covid-19 vaccination on unvaccinated household members. 2021.

145 Shah ASV, Gribben C, Bishop J, et al. Effect of vaccination on transmission of COVID-19: an observational study in healthcare workers and their households. 2021.

146 Levine-Tiefenbrun M, Yelin I, Katz R, et al. Initial report of decreased SARS-CoV-2 viral load after inoculation with the BNT162b2 vaccine. Nat Med 2021; 27: 790-2.

147 Dong E, Du H, Gardner L. An interactive web-based dashboard to track COVID-19 in real time. Lancet Infect Dis 2020; published online Feb 19. DOI:10.1016/S1473-3099(20)30120-1.

148 Shu Y, McCauley J. GISAID: Global initiative on sharing all influenza data - from vision to reality. Eurosurveillance 2017; 22: 30494. 
medRxiv preprint doi: https://doi.org/10.1101/2021.09.17.21263549; this version posted September 25, 2021. The copyright holder for this preprint (which was not certified by peer review) is the author/funder, who has granted medRxiv a license to display the preprint in perpetuity.

It is made available under a CC-BY 4.0 International license . 
medRxiv preprint doi: https://doi.org/10.1101/2021.09.17.21263549; this version posted September 25, 2021. The copyright holder for this preprint (which was not certified by peer review) is the author/funder, who has granted medRxiv a license to display the preprint in perpetuity. It is made available under a CC-BY 4.0 International license .

FIGURES \& TABLES

\begin{tabular}{|c|c|c|c|c|c|c|c|c|c|}
\hline \multirow[b]{2}{*}{ Vaccine Name } & & \multirow[b]{2}{*}{$\begin{array}{c}\text { Vaccine } \\
\text { type }\end{array}$} & \multirow[b]{2}{*}{ WHO Status } & \multicolumn{2}{|c|}{ Countries } & \multicolumn{3}{|c|}{ Phase 3 Efficacy Trial } & \multirow[b]{2}{*}{ Ref } \\
\hline & & & & Developed in & $\begin{array}{c}\text { \# Using as } \\
\text { of } 15 / 9 / 21\end{array}$ & Data? & Cls? & $\begin{array}{c}\text { Peer } \\
\text { reviewed? }\end{array}$ & \\
\hline $\begin{array}{l}\text { AstraZeneca/ } \\
\text { Oxford }\end{array}$ & $\begin{array}{l}\text { AZD1222 } \\
\text { ChAdOx1- } \\
\text { nCoV-19 }\end{array}$ & viral vector & EUL Authorized & UK & 121 & Yes & Yes & Yes & $38,50,51,55$ \\
\hline $\begin{array}{l}\text { Pfizerl } \\
\text { BioNTech }\end{array}$ & BNT162b2 & mRNA & EUL Authorized & Germany & 97 & Yes & Yes & Yes & $22,41,56$ \\
\hline $\begin{array}{l}\text { Gamaleya } \\
\text { Institute }\end{array}$ & $\begin{array}{l}\text { Sputnik V } \\
\text { Gam-COVID-Vac }\end{array}$ & viral vector & $\begin{array}{l}\text { Submission } \\
\text { in Progress }\end{array}$ & Russia & 71 & Yes & Yes & Yes & 42 \\
\hline Moderna & mRNA-1273 & mRNA & EUL Authorized & USA & 68 & Yes & Yes & Yes & 37 \\
\hline $\begin{array}{l}\text { Sinopharm- } \\
\text { Beijing }\end{array}$ & BBIBP-CorV & $\begin{array}{l}\text { inactivated } \\
\text { virus }\end{array}$ & EUL Authorized & China & 60 & Yes & Yes & Yes & 57 \\
\hline $\begin{array}{l}\text { Janssen/ } \\
\text { Johnson \& } \\
\text { Johnson }\end{array}$ & Ad26.COV2.S & viral vector & EUL Authorized & USA & 59 & Yes & Yes & Yes & 36 \\
\hline Sinovac & CoronaVac & $\begin{array}{l}\text { inactivated } \\
\text { virus }\end{array}$ & EUL Authorized & China & 39 & Yes & Yes & Yes & $43,44,58$ \\
\hline Bharat Biotech & BBV152 & $\begin{array}{l}\text { inactivated } \\
\text { virus }\end{array}$ & EOI Accepted & India & 9 & Yes & Yes & No & 35 \\
\hline CanSinoBIO & Ad5-nCoV & viral vector & EOI Accepted & China & 8 & Yes & No & No & \\
\hline $\begin{array}{l}\text { Anhui Zhifei } \\
\text { Longcom }\end{array}$ & ZIFIVAX & $\begin{array}{l}\text { protein } \\
\text { subunit }\end{array}$ & $\begin{array}{l}\text { Submission } \\
\text { in Progress }\end{array}$ & China & 2 & No & No & No & \\
\hline BioCubaFarma & $\begin{array}{l}\text { Soberana } 02 \\
\text { FINLAY-FR-2 }\end{array}$ & conjugate & $\begin{array}{l}\text { Submission } \\
\text { in Progress }\end{array}$ & Cuba & 2 & Yes & Yes & No & 59 \\
\hline Vector Institute & EpiVacCorona & $\begin{array}{l}\text { protein } \\
\text { subunit }\end{array}$ & $\begin{array}{l}\text { Submission } \\
\text { in Progress }\end{array}$ & Russia & 2 & No & No & No & \\
\hline BioCubaFarma & $\begin{array}{l}\text { Abdala } \\
\text { CIGB-66 }\end{array}$ & $\begin{array}{l}\text { protein } \\
\text { subunit }\end{array}$ & $\begin{array}{l}\text { Submission } \\
\text { in Progress }\end{array}$ & Cuba & 1 & Yes & Yes & No & 60 \\
\hline BioKangtai & KCONVAC & $\begin{array}{l}\text { inactivated } \\
\text { virus }\end{array}$ & $\begin{array}{l}\text { Submission } \\
\text { in Progress }\end{array}$ & China & 1 & No & No & No & \\
\hline $\begin{array}{l}\text { Chumakov } \\
\text { Center }\end{array}$ & KoviVac & $\begin{array}{l}\text { inactivated } \\
\text { virus }\end{array}$ & $\begin{array}{l}\text { Submission } \\
\text { in Progress }\end{array}$ & Russia & 1 & No & No & No & \\
\hline IMBCAMS & Covidful & $\begin{array}{l}\text { inactivated } \\
\text { virus }\end{array}$ & $\begin{array}{l}\text { Submission } \\
\text { in Progress }\end{array}$ & China & 1 & No & No & No & \\
\hline $\begin{array}{l}\text { Sinopharm- } \\
\text { Wuhan }\end{array}$ & WIBP-CorV & $\begin{array}{l}\text { inactivated } \\
\text { virus }\end{array}$ & EOI Accepted & China & 1 & Yes & Yes & Yes & 57 \\
\hline $\begin{array}{l}\text { Kazakhstan } \\
\text { RIBSP }\end{array}$ & QazCovid-in & $\begin{array}{l}\text { inactivated } \\
\text { virus }\end{array}$ & $\begin{array}{l}\text { Submission } \\
\text { in Progress }\end{array}$ & Kazakhstan & 1 & No & No & No & \\
\hline Shifa & COVIran Barakat & $\begin{array}{l}\text { inactivated } \\
\text { virus }\end{array}$ & $\begin{array}{l}\text { Submission } \\
\text { in Progress }\end{array}$ & Iran & 1 & No & No & No & \\
\hline BioCubaFarma & $\begin{array}{l}\text { Soberana 02+ } \\
\text { FINLAY-FR-1A }\end{array}$ & $\begin{array}{l}\text { protein } \\
\text { subunit }\end{array}$ & $\begin{array}{l}\text { Submission } \\
\text { in Progress }\end{array}$ & Cuba & 0 & Yes & Yes & No & 59 \\
\hline Clover & SCB-2019 & $\begin{array}{l}\text { protein } \\
\text { subunit }\end{array}$ & $\begin{array}{l}\text { Submission } \\
\text { in Progress }\end{array}$ & China & 0 & No & No & No & \\
\hline CureVac & CVnCoV & mRNA & EOI Accepted & Germany & 0 & Yes & No & No & \\
\hline Novavax & NVX-CoV2373 & $\begin{array}{l}\text { protein } \\
\text { subunit }\end{array}$ & EOI Accepted & USA & 0 & Yes & Yes & Yes & $39,40,52$ \\
\hline Sanofi & $\begin{array}{l}\text { CoV2 pres } \\
\text { dTM-AS03 }\end{array}$ & $\begin{array}{l}\text { protein } \\
\text { subunit }\end{array}$ & EOI Accepted & France & 0 & No & No & No & \\
\hline
\end{tabular}


medRxiv preprint doi: https://doi.org/10.1101/2021.09.17.21263549; this version posted September 25, 2021. The copyright holder for this preprint (which was not certified by peer review) is the author/funder, who has granted medRxiv a license to display the preprint in perpetuity.

It is made available under a CC-BY 4.0 International license .

Table 1: Status of COVID-19 vaccines within the World Health Organization Emergency Use Listing evaluation process. Vaccine products are listed in descending order based on the number of countries in which the vaccine is currently in use. Vaccines included in the current study - based on availability of efficacy data from Phase 3 clinical trials - are highlighted in grey. Abbreviations: EUL = emergency use listing, EOI = expression of interest, $\mathrm{Cl}=$ confidence interval. Vaccine details were obtained from McGill University's COVID-19 Vaccine Tracker: https://covid19.trackvaccines.org/, which aggregates data from multiple sources. Original source for WHO EUL status :

https://extranet.who.int/pqweb/key-resources/documents/status-covid-19-vaccines-within-who-eulpq-evaluation-pr ocess 
medRxiv preprint doi: https://doi.org/10.1101/2021.09.17.21263549; this version posted September 25, 2021. The copyright holder for this preprint (which was not certified by peer review) is the author/funder, who has granted medRxiv a license to display the preprint in perpetuity.

It is made available under a CC-BY 4.0 International license .

\begin{tabular}{|c|c|c|c|c|c|c|}
\hline & & \multicolumn{5}{|c|}{ Vaccine } \\
\hline & & $\begin{array}{c}\text { AZD1222 } \\
\text { (Oxford- } \\
\text { AstraZeneca) }\end{array}$ & $\begin{array}{l}\text { BNT162b2 } \\
\text { (Pfizer- } \\
\text { BioNTech) }\end{array}$ & $\begin{array}{l}\text { CoronaVac } \\
\text { (Sinovac) }\end{array}$ & $\begin{array}{c}\text { mRNA-1273 } \\
\text { (Moderna) }\end{array}$ & $\begin{array}{c}\text { Ad26.COV2.S } \\
\text { (Janssen/Johnson } \\
\text { \& Johnson) }\end{array}$ \\
\hline Total & (Number) & 22 & 51 & 2 & 14 & 2 \\
\hline \multicolumn{7}{|c|}{ Outcome type } \\
\hline & Death & 1 & 6 & 2 & 0 & 0 \\
\hline & Severe disease & 10 & 22 & 2 & 7 & 0 \\
\hline & Symptomatic disease & 9 & 19 & 1 & 5 & 0 \\
\hline & Asymptomatic & & & & & \\
\hline & infection & 0 & 5 & 0 & 1 & 0 \\
\hline & Any infection & 11 & 34 & 1 & 11 & 2 \\
\hline \multicolumn{7}{|c|}{ Population type } \\
\hline & General population & 12 & 24 & 1 & 10 & 1 \\
\hline & Health care workers & 1 & 9 & 0 & 2 & 0 \\
\hline & Hospital patients & 1 & 4 & 0 & 1 & 0 \\
\hline & LTCF residents & 1 & 3 & 0 & 0 & 0 \\
\hline & $\begin{array}{l}\text { Older adults ( } \geq 65 \\
\text { years) }\end{array}$ & 7 & 10 & 1 & 1 & 0 \\
\hline & Chronically ill & 1 & 0 & 0 & 0 & 0 \\
\hline & Pregnant women & 0 & 1 & 0 & 0 & 0 \\
\hline & Priority groups & 0 & 1 & 0 & 0 & 0 \\
\hline \multicolumn{7}{|c|}{ Study design } \\
\hline & $\begin{array}{l}\text { Test-negative case } \\
\text { control }\end{array}$ & 9 & 18 & 1 & 9 & 0 \\
\hline & $\begin{array}{l}\text { Traditional } \\
\text { case-control }\end{array}$ & 0 & 2 & 0 & 0 & 0 \\
\hline & Prospective cohort & 6 & 11 & 1 & 1 & 0 \\
\hline & Retrospective cohort & 6 & 20 & 0 & 5 & 2 \\
\hline & Screening method & 1 & 2 & 0 & 0 & 0 \\
\hline \multicolumn{7}{|c|}{ \# of doses } \\
\hline & Complete & 6 & 33 & 2 & 8 & 1 \\
\hline & Partial & 18 & 36 & 2 & 9 & $\mathrm{~N} / \mathrm{A}$ \\
\hline & Both & 9 & 30 & 2 & 0 & \\
\hline \multicolumn{7}{|c|}{ Variants of concern } \\
\hline & Alpha & 4 & 6 & 0 & 3 & 0 \\
\hline & Beta & 0 & 2 & 0 & 2 & 0 \\
\hline & Gamma & 0 & 0 & 0 & 0 & 0 \\
\hline & Delta & 4 & 5 & 0 & 1 & 0 \\
\hline
\end{tabular}

Table 2. Summary of vaccine effectiveness studies. Number of studies of each type included in the review. No studies reported for other vaccine candidates met our inclusion criteria (see Methods). Details of all the individual studies are included in Table S1. 


\section{A. COVID-19 vaccine trials in Brazil}

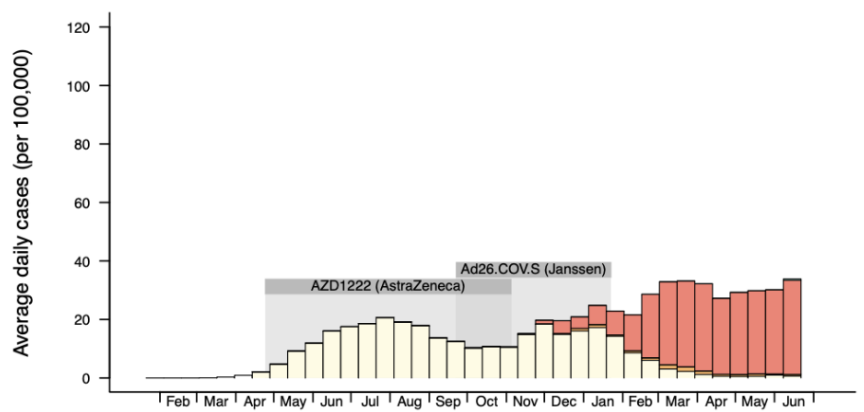

C. CovID-19 vaccine trials in Russia

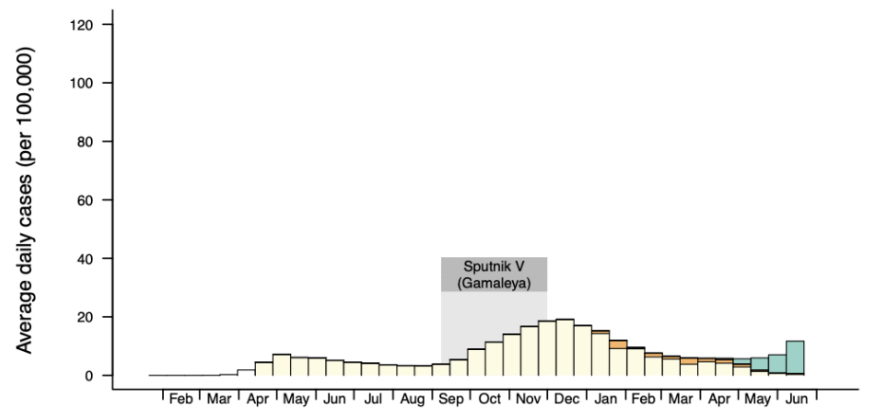

E. COVID-19 vaccine trials in Turkey

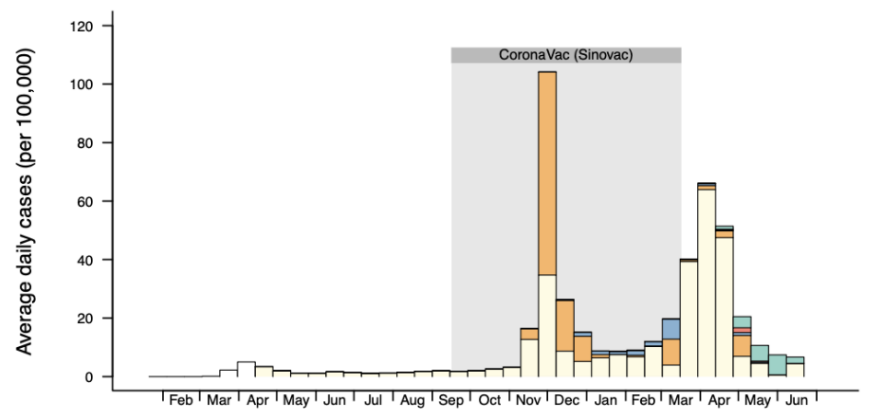

G. COVID-19 vaccine trials in United States

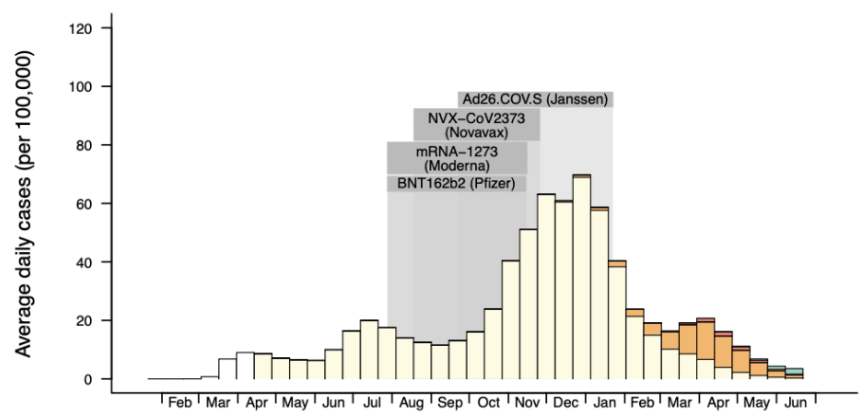

\section{B. COVID-19 vaccine trials in India}

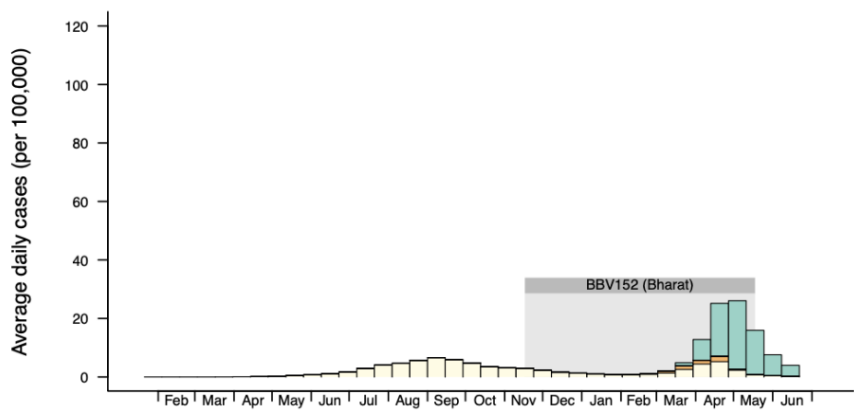

D. COVID-19 vaccine trials in South Africa

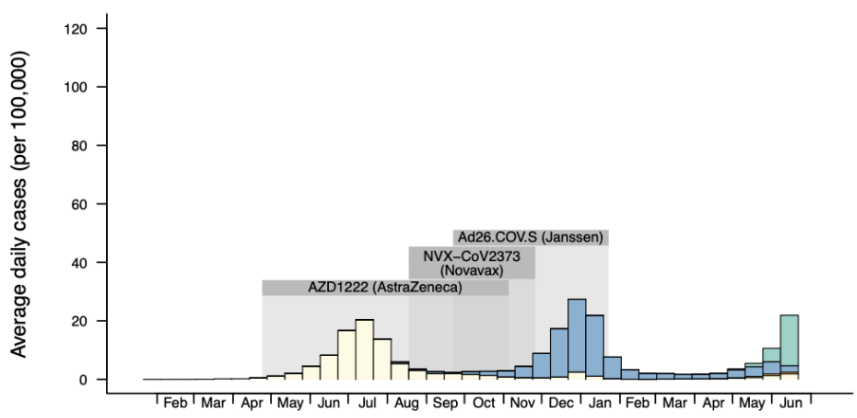

F. COVID-19 vaccine trials in United Kingdom

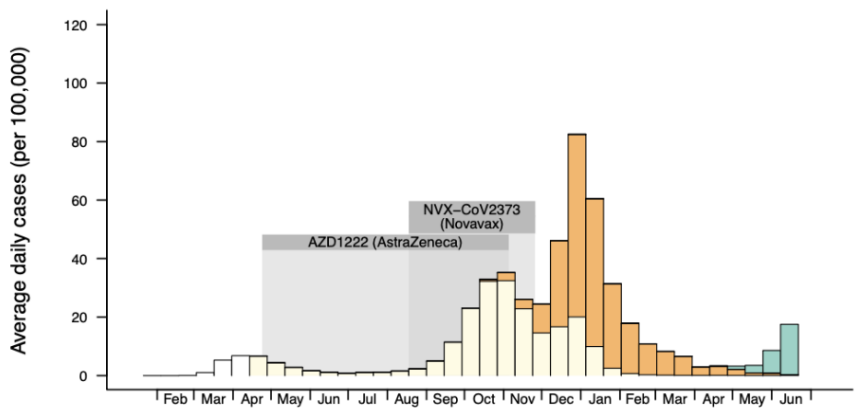

Figure 1. Local context of Phase 3 clinical trials of COVID-19 vaccines. For each country, the time period during which outcomes were observed during each vaccine trial is shaded grey. For each two week period, the average daily incidence of reported cases is shown (height of bars) ${ }^{147}$. The contribution of each major variant of concern to total case counts is estimated from the reported fraction of sequenced SARS-CoV-2 samples belonging to that strain (fill color) ${ }^{148}$. Figure includes only vaccine trials described in published or pre-print reports, trial sites with at least 10,000 individuals from the general adult population, and countries regularly reporting SARS-CoV-2 lineages to the GISAID database. 
medRxiv preprint doi: https://doi.org/10.1101/2021.09.17.21263549; this version posted September 25, 2021. The copyright holder for this preprint (which was not certified by peer review) is the author/funder, who has granted medRxiv a license to display the preprint in perpetuity.

It is made available under a CC-BY 4.0 International license .

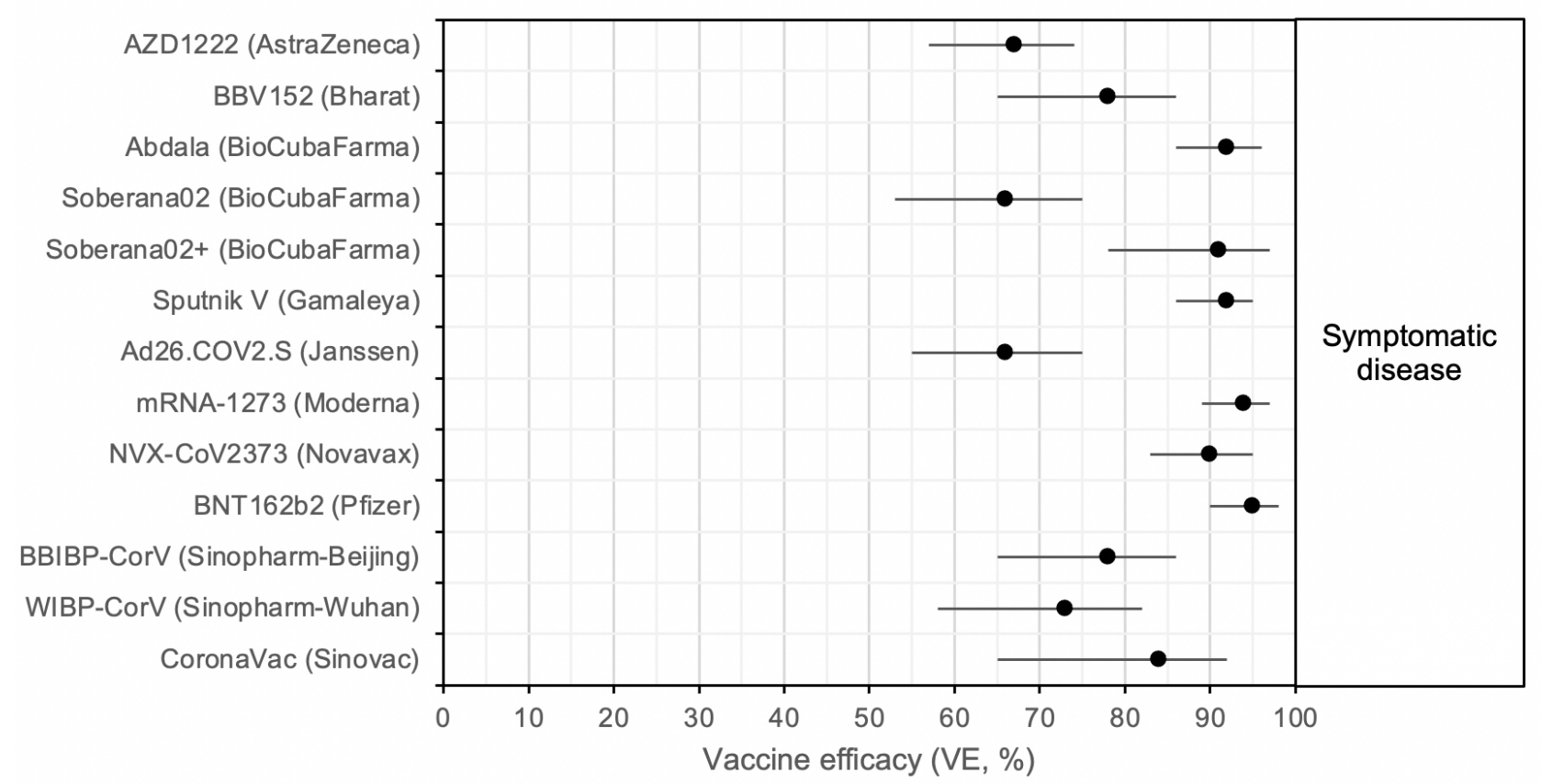

Figure 2. Vaccine efficacy (VE) against symptomatic COVID-19, from Phase 3 clinical trials. Each efficacy value is for the complete vaccine course (1 dose for Ad26.COV2.S/Janssen, 3 doses for BioCubaFarma/Abdala and Soberana02+/BioCubaFarma, and 2 doses for all others). 
medRxiv preprint doi: https://doi.org/10.1101/2021.09.17.21263549; this version posted September 25, 2021. The copyright holder for this preprint (which was not certified by peer review) is the author/funder, who has granted medRxiv a license to display the preprint in perpetuity.

It is made available under a CC-BY 4.0 International license .

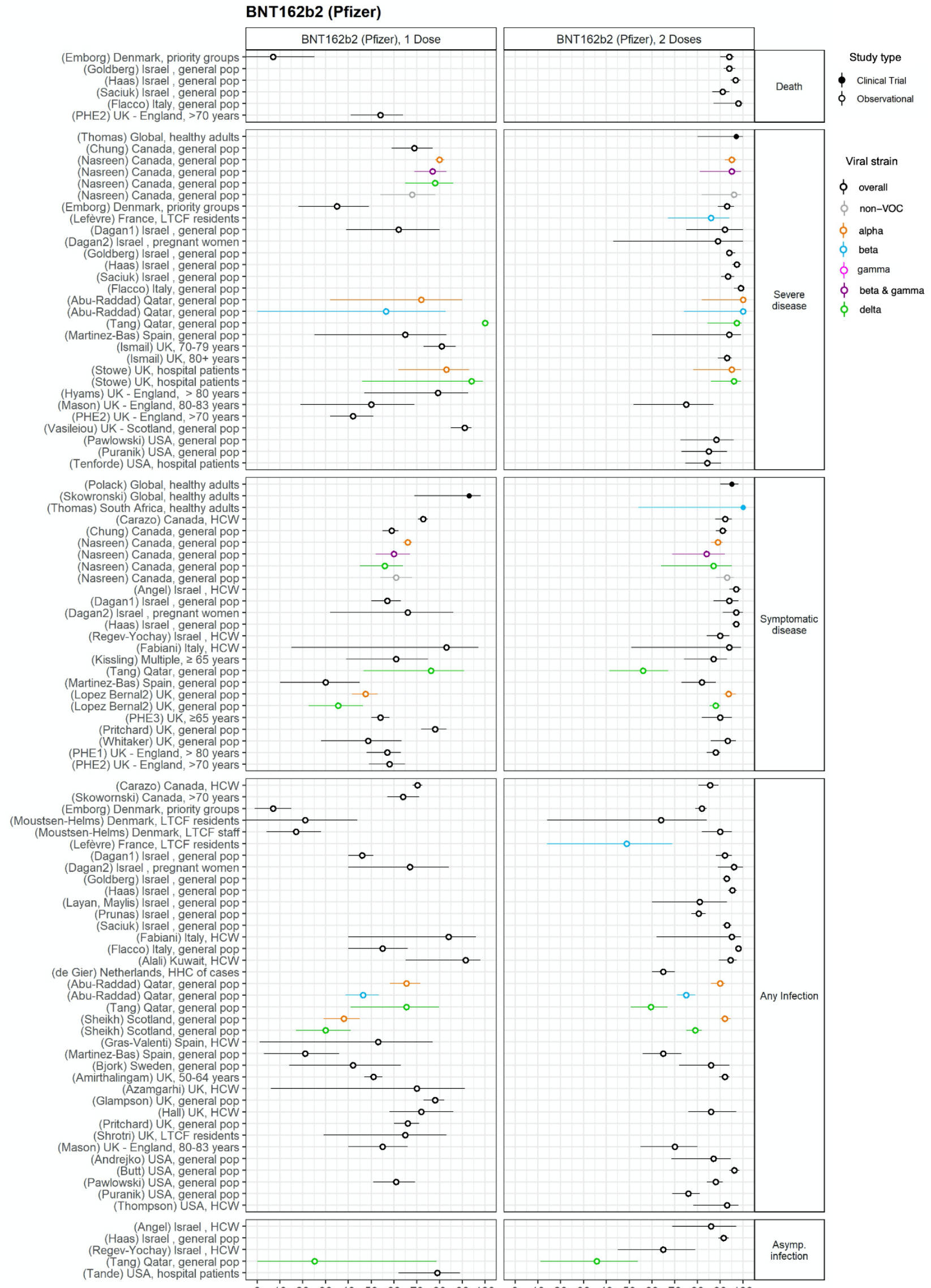

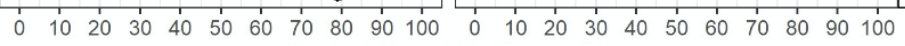
Vaccine efficacy/effectiveness (VE, \%) 
medRxiv preprint doi: https://doi.org/10.1101/2021.09.17.21263549; this version posted September 25, 2021. The copyright holder for this preprint (which was not certified by peer review) is the author/funder, who has granted medRxiv a license to display the preprint in perpetuity.

It is made available under a CC-BY 4.0 International license .

Figure 3. Vaccine efficacy and effectiveness ("VE") estimates for BNT162b2, a two-dose mRNA vaccine developed by Pfizer/BioNTech. Estimates are colored by the viral variant against which the VE value was measured. Solid markers are estimates from randomized clinical trials (efficacy values), and open markers are estimates from observational studies (effectiveness values). The source of each estimate is given by the labels on the left side ( "(reference number) Country, population"). Within each disease severity level, estimates are ordered alphabetically by country, and then by population 
medRxiv preprint doi: https://doi.org/10.1101/2021.09.17.21263549; this version posted September 25, 2021. The copyright holder for this preprint (which was not certified by peer review) is the author/funder, who has granted medRxiv a license to display the preprint in perpetuity.

It is made available under a CC-BY 4.0 International license .

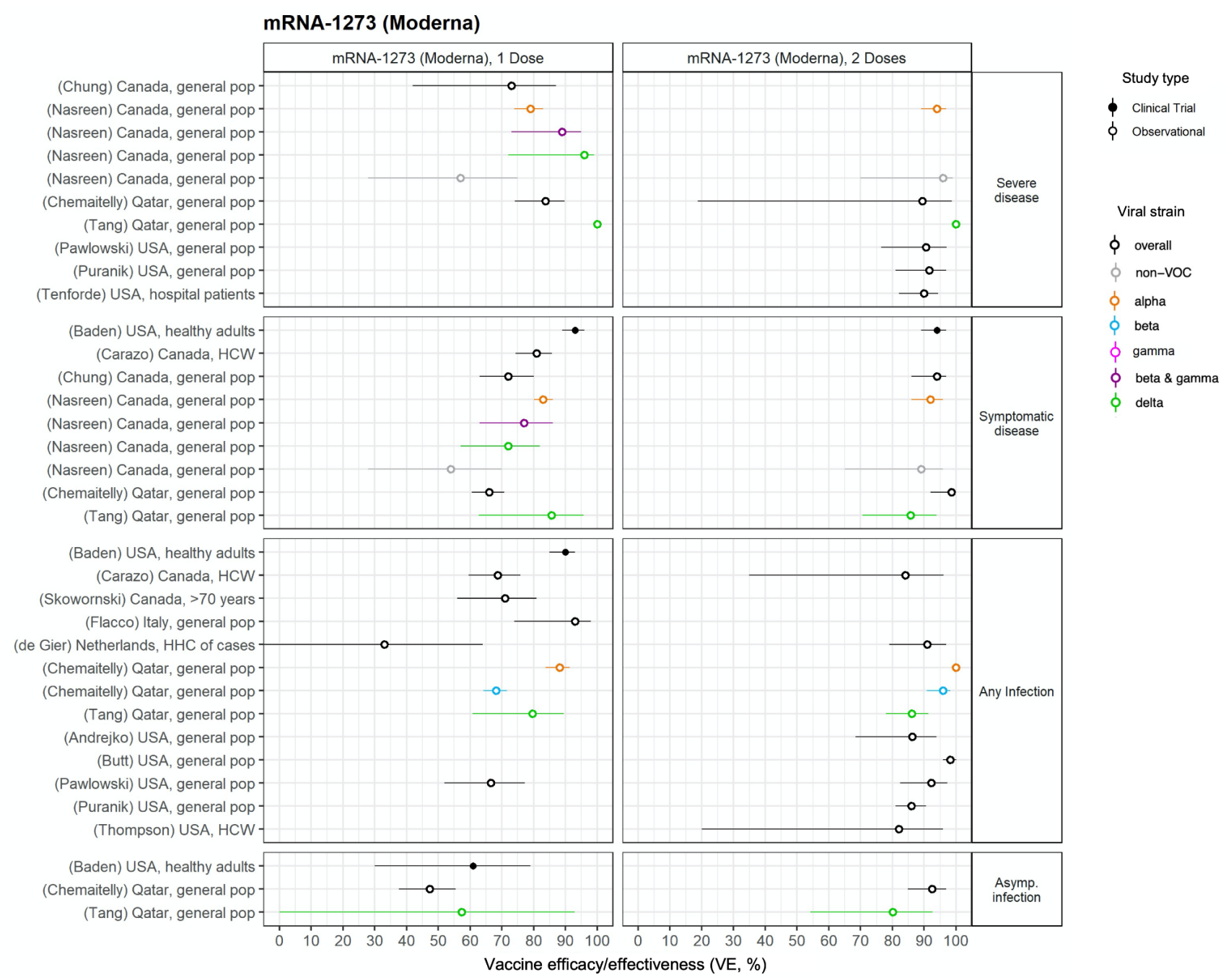

Figure 4. Vaccine efficacy and effectiveness (“VE”) estimates for mRNA-1273, a two-dose mRNA vaccine developed by Moderna. Estimates are colored by the viral variant against which the VE value was measured. Solid markers are estimates from randomized clinical trials (efficacy values), and open markers are estimates from observational studies (effectiveness values). The source of each estimate is given by the labels on the left side ( "(reference number) Country, population"). Within each disease severity level, estimates are ordered alphabetically by country, and then by population. 
medRxiv preprint doi: https://doi.org/10.1101/2021.09.17.21263549; this version posted September 25, 2021. The copyright holder for this preprint (which was not certified by peer review) is the author/funder, who has granted medRxiv a license to display the preprint in perpetuity.

It is made available under a CC-BY 4.0 International license .

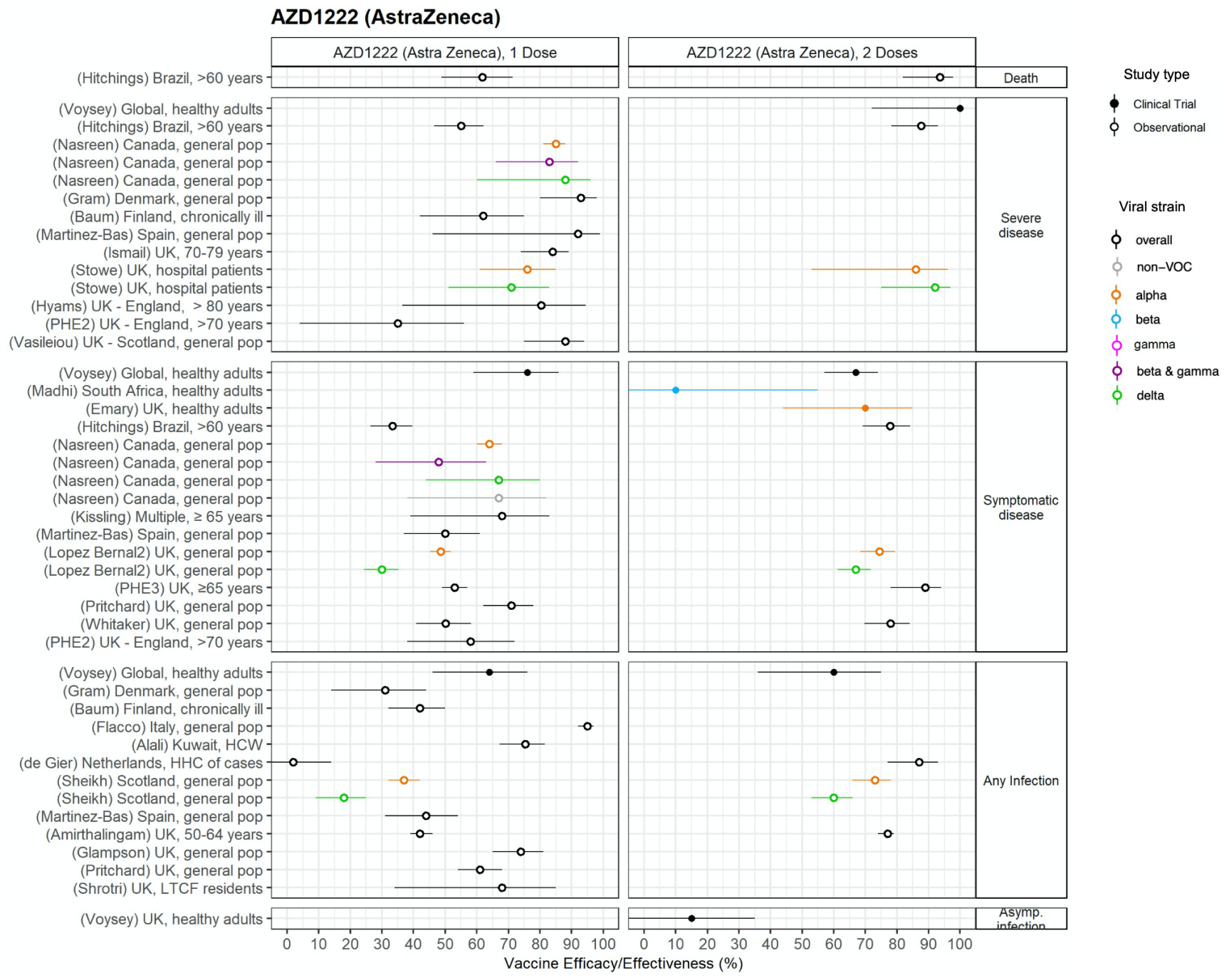

Figure 5. Vaccine efficacy and effectiveness (“VE”) estimates for AZD1222, a two-dose viral vector vaccine developed by AstraZeneca. Estimates are colored by the viral variant against which the VE value was measured. Solid markers are estimates from randomized clinical trials (efficacy values), and open markers are estimates from observational studies (effectiveness values). The source of each estimate is given by the labels on the left side ( "(reference number) Country, population"). Within each disease severity level, estimates are ordered alphabetically by country, and then by population. 


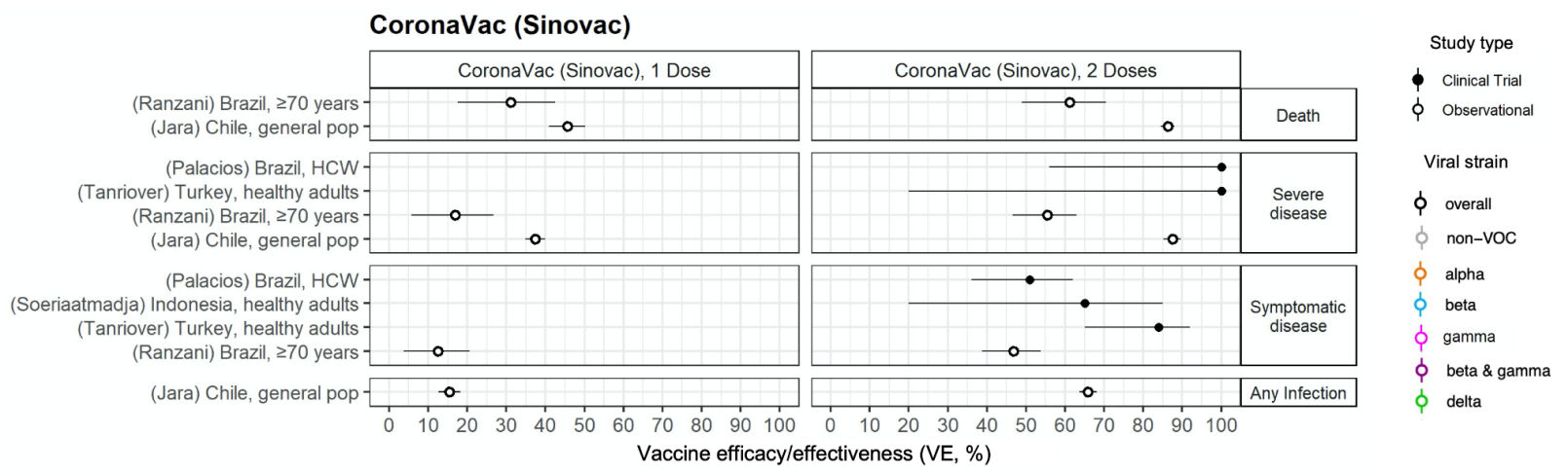

Figure 6. Vaccine efficacy and effectiveness ("VE") estimates for CoronaVac, a two-dose inactivated virus vaccine developed by Sinovac. Estimates are colored by the viral variant against which the VE value was measured. Solid markers are estimates from randomized clinical trials (efficacy values), and open markers are estimates from observational studies (effectiveness values). The source of each estimate is given by the labels on the left side ( "(reference number) Country, population"). Within each disease severity level, estimates are ordered alphabetically by country, and then by population.

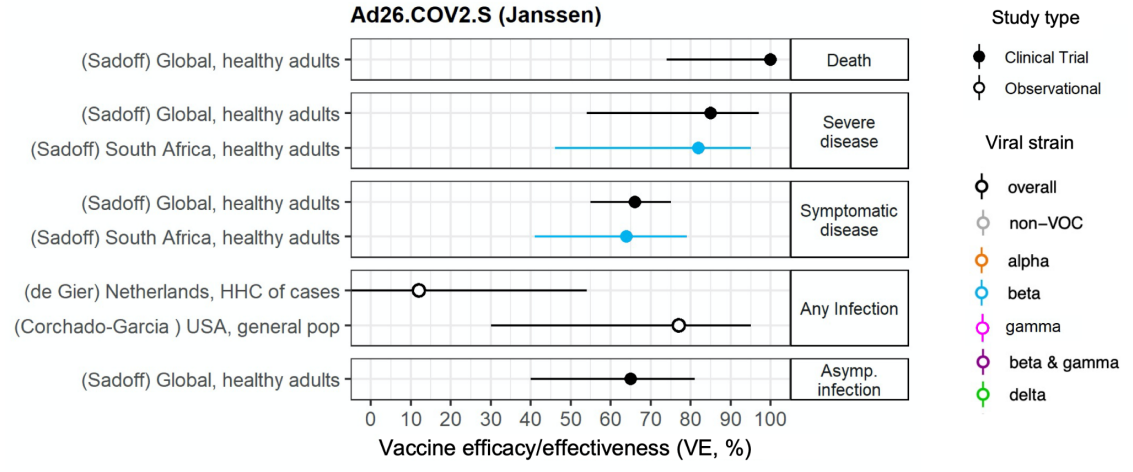

Figure 7. Vaccine efficacy and effectiveness ("VE") estimates for Ad26.COV2.S, a single-dose viral vector vaccine developed by Janssen/Johnson \& Johnson. Estimates are colored by the viral variant against which the VE value was measured. Solid markers are estimates from randomized clinical trials (efficacy values), and open markers are estimates from observational studies (effectiveness values). The source of each estimate is given by the labels on the left side ( "(reference number) Country, population"). Within each disease severity level, estimates are ordered alphabetically by country, and then by population. 
medRxiv preprint doi: https://doi.org/10.1101/2021.09.17.21263549; this version posted September 25, 2021. The copyright holder for this preprint (which was not certified by peer review) is the author/funder, who has granted medRxiv a license to display the preprint in perpetuity.

It is made available under a CC-BY 4.0 International license .

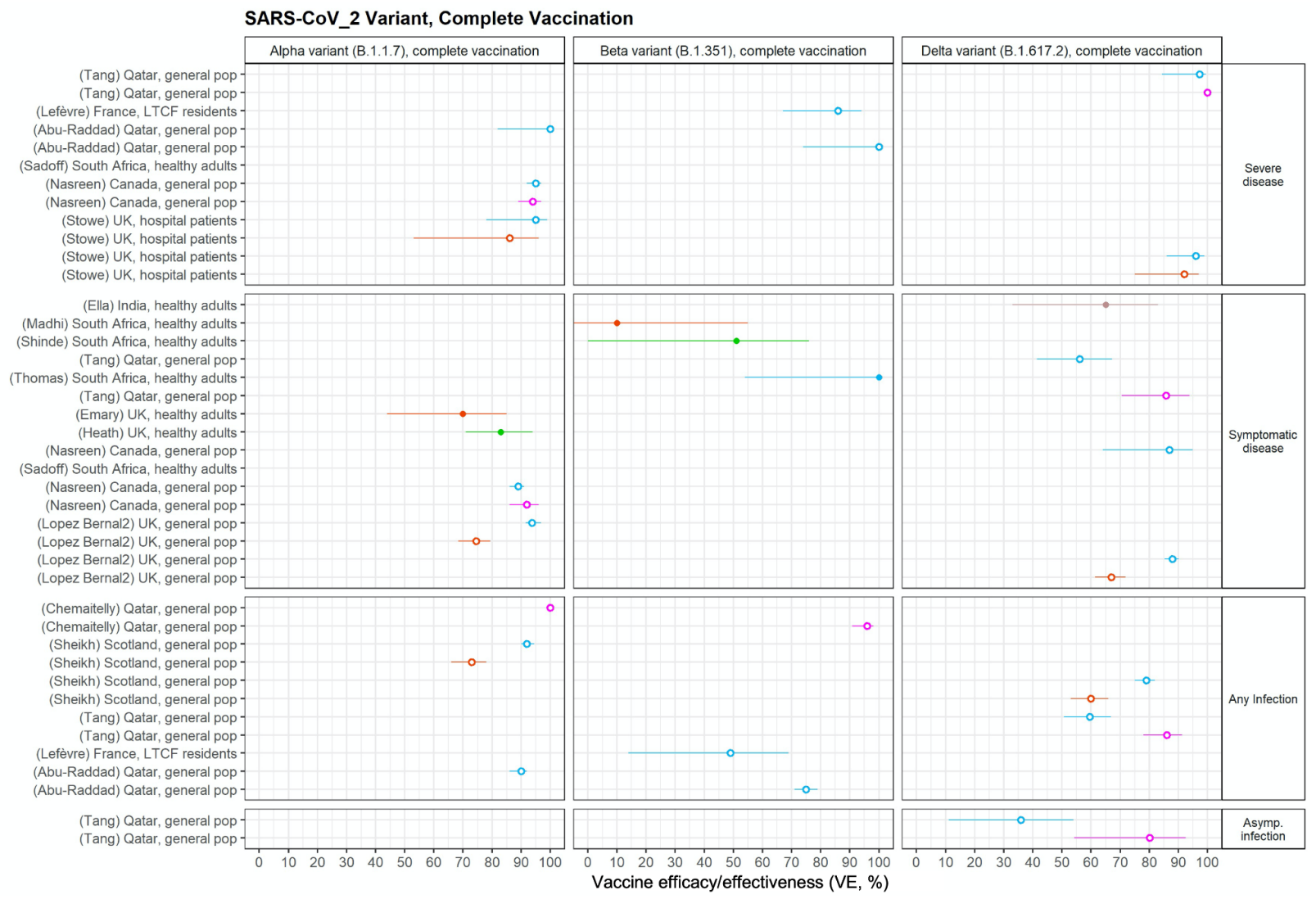

$\begin{array}{llll}\text { Study type } & \text { Vaccine } & \\ \phi \text { Clinical Trial } & \text { Ad26.COV2.S (Janssen) } & \text { mRNA-1273 (Moderna) } \\ \phi \text { Observational } & \phi \text { AZD1222 (AstraZeneca) } & \text { NVX-CoV2373 (Novavax) } \\ & \phi \text { BNT162b2 (Pfizer) } & \text { BBV152 (Bharat) }\end{array}$

Figure 8. Vaccine efficacy and effectiveness ("VE", \%) estimates by SARS-CoV-2 variants of concern. Estimates are colored by the vaccine for which the VE value was measured. Solid markers are estimates from randomized clinical trials (efficacy values), and open markers are estimates from observational studies (effectiveness values). The source of each estimate is given by the labels on the left side ( "(reference number) Country, population"). Within each disease severity level, estimates are ordered alphabetically by country, and then by population. 